\title{
A comparison of units for visually measuring facial actions
}

\author{
JOSEPH C. HAGER \\ Research Nexus, San Francisco, Califormia
}

\begin{abstract}
Visual inspection and categorization of facial appearances constitute the most frequent and useful technique for measuring facial activity. The techniques developed, however, have different units with varying characteristics. In this paper, I discuss categorical and scalar units for facial measurement and show the relationship of categorical units listed by different researchers.
\end{abstract}

Techniques that enable investigators to precisely describe and quantify facial muscular actions are essential for exploring the relationships between facial behaviors and emotion, nonverbal communication, personality, neural activity, etc. A recent surge of interest in the face (e.g., Fridlund, Ekman, \& Oster, 1985) has fostered searches for improved measurement methods and has increased the number of such techniques. This article examines units of measurement that categorize facial behaviors based on visual appearance. To aid detailed comparison of units, Appendixes A and B show the relationship of units from several important methods. To create these charts, I "translated" the various units into equivalent terms. Only methods of measuring quickly occurring facial changes, or "rapid sign vehicles" (Ekman, 1978), are considered here; I do not consider methods for assessing slower changes arising from aging or other factors (e.g., Todd, Mark, Shaw, \& Pittenger, 1980).

My focus is on the units of measurement: their characteristics and correspondence across methods. More general aspects of facial measurement methods are not discussed here, in part because Ekman (1982) presents a thorough review. He compares 14 measurement methods on general characteristics, such as theoretical rationales; methods of devising units; comprehensiveness of methods in capturing possible behaviors, timing, and intensity of expressions; adequacy of the units' descriptions; reliability; and validity. All of the measurement methods translated here in Appendixes A and B are compared in Ekman's tables, to which the reader should refer for a complementary analysis.

The translation of units is based on definitions, not on empirical comparisons. (This distinction is discussed in detail below.) To show the background for translating units, I first examine the rationale for categorical units and their important features. Then I discuss scalar measurement units to show that they can extend the power of categories and to complete an overview of facial mea-

Thanks to Paul Ekman, Robert Levenson, Wallace V. Friesen, and anonymous reviewers for reading previous versions of this manuscript. Address comments and reprint requests to Research Nexus, P. O. Box 883843, San Francisco, CA 94188-3843. surement units. A discussion of comparing and translating categorical units follows. Finally, some examples illustrate use of the appendixes.

\section{VISUAL CATEGORICAL MEASUREMENT}

Most techniques that measure facial actions or expressions use a set of categories to distinguish among visible facial changes. For example, an expression in the forehead might be categorized as "raised brows" or "puzzled frown"; a movement of the lips may be categorized as action of zygomatic major or triangularis. The emphasis on visible appearances reflects the fact that much of the interest in facial expressions is related to their value as social signals, and the visual aspects of facial action are of the greatest significance in this regard. The complexity of expressive configurations and their transformations is challenging to investigators seeking alternatives to the human visual and nervous sytems for categorizing facial expressions. ${ }^{1}$

Reliance on category scores (nominal measurement units) reflects the limitations of known quantitative continua for discriminating the diversity of facial muscular activities and patterns. Some quantitatively oriented psychologists (e.g., Nunnally, 1967) suggest that nominal units should be considered a way to identify or describe rather than to measure. Yet, in the present instance, the value of categorical versus scalar units as the basis for measurement is related more to the research question than to the mathematical properties of the measurements. Many of the important aspects of facial behavior seem to be represented best by qualitative differences that can be detected visually. The need for quantitative or scalar measurement units becomes apparent, however, as new questions arise about the relation of facial expression to neural action (Hager \& Ekman, 1985), emotional feelings (Ekman, Friesen, \& Ancoli, 1980; Schwartz, Ahern, \& Brown, 1979), and other phenomena. For these issues, the visual and social aspects of expression become less important, and more subtle gradations in actions of targeted facial muscles become more important.

Despite the need for improved scalar measurement units, categorical units represent what happens qualita- 
tively in the face, and these distinctions are often crucial precursors to quantifying how much happens. Although categorical units do not express any quantity of an attribute (except binary presence or absence), frequency counts, rates, and durations of category scores provide the basis for quantitative analysis. The ideas behind the mathematics of sets have proved useful to investigators who have grouped nominal units into subsets which reflect various types of behaviors. For example, Ekman (1979) discusses distinctions among brow movements. He notes that brow raises in response to feeling sadness, fear, and surprise, can be distinguished from anger brows, which are lowered. However, distinguishing among sad, surprise, and fear brow raises requires units that can identify different brow raises. Ekman examines the intersection of these subsets. Anger, fear, and sad brows, but not surprise brows, may include action of corrugator. Fear and surprise brows, but not sad and anger brows, may include action of the lateral frontalis. Other mathematical approaches also can extend the value of category scores. Applying time-series analysis to category scores, Gottman (1981) shows how sophisticated data analysis can detect relations among behaviors over time.

Category scores are refinements of more informal ways for categorizing facial behaviors, such as Darwin's (1872) and Tomkins's (1962) descriptive classifications of emotional expressions. These authors, by careful observation and inference, were able to specify the essential differences in facial appearance that distinguish emotions. They used drawings, photographs, and verbal descriptions to convey these appearances, but did not create a systematic method for analyzing how an observed expression could be matched to one of these categories.

Categorical measurement is different from the use of informal judgments of naive observers to assess facial signals and appearances (e.g., Tomkins \& McCarter, 1964). Unlike such observers' judgments of the meanings of expressions, facial measurement techniques attempt to specify what the face does rather than what meanings observers infer from it (see Ekman, 1982, and Ekman, Friesen, \& Ellsworth, 1982, for discussions of facial measurement vs. message judgment approaches). For their application, measurement units require standard rules rather than idiosyncratic decisions of judges. All the methods discussed here are measurement techniques, not judgment approaches. (For analyses of judgment studies, see Ekman et al., 1982, and Rosenthal, 1982).

To create categorical units, the researcher must choose whether to define measurement units by simple, elementary movements or by larger gestalts. This decision leads to variation in the "size" of units (i.e., the number of activities included in units). Size of units varies within a technique as well as between different techniques, but methods that attempt to measure elementary units generally use smaller units than methods that catalog observed behaviors. For example, Young and Decarie's (1977) units classify the face as a whole. Ekman, Friesen, and Tomkins (1971) separately classify each of three areas of the face. Ekman and Friesen (1978) classify appearances produced by individual muscular actions.

The meaning of units is related to unit size. Many units that are gestalts were constructed on the basis of the meaning the author attributed to them, such as shifty eyes, weeping, aggressive frown, sneer, and pout (see Appendix B). Izard, Dougherty, and Hembree's (1980) Affex is based entirely on inferential units. In this technique, observers make inferences about the emotional meanings of expressions rather than categorize the specific actions involved in the expression. Ekman (1982) discusses the problematic nature of scores that are based on inference, including the possibility of biasing scorers, the multiple or ambiguous meanings of single muscular actions, and the lack of comprehensive coverage of possible actions (especially for nonemotional messages).

Elementary units, in contrast to gestalts, are often based on anatomical or visual distinctions rather than meaning. To fit into these elementary units, facial expressions composed of multiple muscular actions are typically broken down into their components by scorers. One problem with elementary units is that, after being scored, they need to be reconfigured into a representation of the original expression, and then meaning is assigned to the reconfigured scores. This reconfiguration may depend upon the category, timing, and intensity of the units measured. Another problem with elementary units is that scoring all the possible facial actions may be too detailed for an investigator's purpose, such as the need to measure only actions relevant to emotion. Ekman and Friesen (1978) are the only investigators who have sytematically addressed these problems.

Friesen and Ekman (1984) created EMFACS to solve the problems of configuring elementary units into events and assigning meaning to these configurations. EMFACS is a guide for scoring only those units in Ekman and Friesen's (1976, 1978) Facial Action Coding System (FACS) that are thought to be relevant to emotion. Using EMFACS, the scorer focuses on critical actions that Friesen and Ekman determined, on theoretical and empirical grounds, to be involved in emotional expressions (see Table 1). Other actions occurring with the critical actions are also scored if they meet explicit criteria for timing and intensity. With the help of these rules, the coder decides which actions in the stream of behavior belong together and constitute a single event. Later, a "dictionary" is used to look up the combinations scored as an event and to determine how the event should be interpreted. There are currently several thousands of combinations possible in the dictionary, too many to count accurately.

The rationale for visual, categorical units for facial measurement has been reviewed. Units are visual because facial expressions are an important visual signal system and because the human visual system is the best way to analyze these complex signals. They are categorical because assignment of facial expressions to categories is the best way to describe and represent many aspects of facial 
Table 1

Key Facial Behaviors for Measuring Emotions

\begin{tabular}{|c|c|c|c|c|}
\hline Emotions & $\begin{array}{l}\text { Friesen \& } \\
\text { Ekman (1984) } \\
\text { EMFACS } \\
\end{array}$ & $\begin{array}{l}\text { Izard (1983) } \\
\text { MAX }\end{array}$ & $\begin{array}{l}\text { Ermiane \& } \\
\text { Gergerian (1978) } \\
\text { HANEST* }\end{array}$ & $\begin{array}{l}\text { Hjortsjo } \\
(1969)\end{array}$ \\
\hline Happy & $\begin{array}{l}12 \\
6+12 \\
7+12\end{array}$ & $38+52$ & $\begin{array}{l}6 \text { Lps } \\
7 \text { Pret } \\
9 \text { Wink } \\
18 \text { Zygmaj } \\
19 \text { Bucc }\end{array}$ & $\begin{array}{l}11 \\
12 \\
13 \\
14\end{array}$ \\
\hline $\begin{array}{l}\text { Sadness, } \\
\text { Distress }\end{array}$ & $\begin{array}{l}1 \text { or } 1+4 \\
15 \\
6+15 \\
11+17 \\
11+15\end{array}$ & $\begin{array}{l}23+33 \\
33 \\
38 \\
23+56 \\
38+56\end{array}$ & $\begin{array}{l}10 \text { Orb } \\
11 \text { Pres } \\
17 \text { Zygmin } \\
23 \text { Tri }\end{array}$ & $\begin{array}{l}1 \\
4 \\
15 \\
17 \\
20+21\end{array}$ \\
\hline Fear & $\begin{array}{l}1+2+4 \\
20\end{array}$ & $\begin{array}{l}22+53 \\
22+31+53 \\
31 \\
53\end{array}$ & $\begin{array}{l}1 \text { Fron } \\
3 \text { Corsup } \\
6 \text { Lps } \\
10 \text { Orb } \\
11 \text { Pres } \\
13 \text { Cnaris } \\
17 \text { Zygmin } \\
21 \text { Plat } \\
23 \text { Tri } \\
27 \text { Ment }\end{array}$ & $\begin{array}{l}1+2 \\
4 \\
18+19 \\
22\end{array}$ \\
\hline $\begin{array}{l}\text { Anger, } \\
\text { Rage }\end{array}$ & $\begin{array}{l}4+5 \\
4+7 \\
4+5+7 \\
17+24 \\
23\end{array}$ & $\begin{array}{l}25+54 \text { or } 55 \\
25+32+54 \text { or } 55 \\
32+54 \text { or } 55\end{array}$ & $\begin{array}{l}3 \text { Corsup } \\
6 \text { Lps } \\
9 \text { Wink } \\
10 \text { Orb } \\
13 \text { Cnaris } \\
14 \text { Dsepti } \\
15 \text { Levlasupan } \\
16 \text { Levlasup } \\
21 \text { Plat } \\
22 \text { Cani } \\
23 \text { Tri } \\
25 \text { Ooris } \\
27 \text { Ment }\end{array}$ & $\begin{array}{l}2 \\
3 \\
5 \\
15 \\
16 \\
17 \\
20+21 \\
23\end{array}$ \\
\hline Surprise & $\begin{array}{l}1+2+5 \text { (low) } \\
1+2+26 \\
1+2+5(\text { low })+26\end{array}$ & $\begin{array}{l}50 \\
20+30+50\end{array}$ & $\begin{array}{l}1 \text { Fron } \\
2 \text { Extfr } \\
6 \text { Lps }\end{array}$ & $\begin{array}{l}1+2 \\
18+19 \\
22\end{array}$ \\
\hline Disgust & $\begin{array}{l}9 \\
10 \text { (only) }\end{array}$ & $\begin{array}{l}25+33 \\
38+59 B+63 \\
63+66 \text { (only) }\end{array}$ & not specified & $\begin{array}{l}1+2 \\
3 \\
5 \\
6+7 \\
8 \\
9 \\
10 \\
16 \\
17 \\
18+19 \\
22+23\end{array}$ \\
\hline
\end{tabular}

Note-This table is not to be used to interpret the emotional meanings of facial expression (see text). The key behaviors for identifying each emotion are listed from three emotion classification systems. To determine the muscular basis of units listed, see Appendixes A and B. * Only Ermiane and Gergerian's "Basic Components" for the five emotions are listed. These authors list other "Auxilliary Components, "gaze directions, and jaw and head positions. 
behavior and because categorization is the precursor to quantification and scalar units. One important characteristic of measurement units is the use of explicit, formal rules for their assignment, in contrast to the use of informal judgments of untrained observers. When considering the relationship between different units, the sizes and bases of the units are useful distinctions. Two important bases for units are the muscular actions that produce the expression and the investigator's inferred meaning of the expression.

\section{SCALAR MEASUREMENT}

Scalar units are the next step beyond categorization in the quantification of facial actions. The most common scalar units for visually measuring appearances are ordinal and typically supplement specific categorical units. In this case, categorical units describe what activity occurs; scalar units describe how much occurs. For example, in early attempts to measure facial behavior (e.g., Landis, 1924; Thompson, 1941), the involvement of each possible categorical unit was rated on a three-point scale, from "extreme" to "no involvement." This approach is improved in later measurement techniques, such as Ekman and Friesen's (1978) FACS with its optional intensity scoring. In FACS the type of behavior is determined prior to and independent of intensity scoring, rather than simultaneous judgments being made of both the category of movement and its intensity. This procedure separates the categorization from the assessment of the extent to which that category occurs. Also, this intensity scoring is guided by explicit rules rather than by implicit, preconceived standards the scorer may have, as in the case of Landis's intensity scoring (1924).

Some authors invented ordinal units that were unattached to specific nominal units. For example, Landis (1924) and Fulcher (1942) devised units that expressed the degree of total facial activity, but the units were merely the crude, subjective ratings of observers. In general, such global indexes of facial expressiveness have not proved informative, perhaps because facial activity is controlled by too many different factors.

A higher level of measurement than an ordinal scale can be obtained by measuring physical displacement of particular landmarks. Again, Landis (1924) was among the first to attempt such an approach. He thought that, by highlighting landmarks on subjects' faces with charcoal, he could physically and objectively measure their changes in position. Landis failed because changes in the subject's head orientation between baseline and expression conditions altered apparent facial proportions on the film record and made comparison difficult. Wolff, Smith, and Murray (1934) attempted to trace projections of photographic images and physically measure changes in landmarks, but they found that their procedure was too time-consuming to employ. Nevertheless, this approach achieved some degree of success in later applications. Lynn (1940) held the subject's head relatively immobile while eliciting smiles and filming them. By identifying landmarks on a projection of the image, he was able to measure position changes in millimeters over fractions of seconds and to devise a ratio of these changes to indicate asymmetries between the two sides of the face. Shor (1978) marked subjects' faces with tabs of adhesive tape and photographed them both before and while they posed smiles with their heads held relatively stationary. From the photographs, he measured changes in the positions of the tabs. Measuring movements of landmarks might provide a more precise measure of the intensity of specific muscular actions than a scorer's unaided judgment, if such movement has a linear correspondence to the action, but no research has been done on this issue.

Rubenstein (1969) measured the area of facial profiles as an index of facial activity. A camera rapidly revolving around the head photographed a series of profiles before and while subjects smiled for the camera. The area of each profile was calculated, and the difference between the before- and during-smiling profiles became a measure of "facial displacement." Although facial displacement changed with smiling, the ability of this method to detect and discriminate different facial actions and the method's correspondence with categorical units is unknown.

Lasko (cited by Ekman, 1982) measured curvature of certain facial areas by superimposing a grid over successive frames of film records and recording landmark changes. These changes were entered into mathematical equations that calculated the changes in the curvature of soft tissues due to movement. Although both Lasko's and Rubenstein's techniques employ novel units of interval scale or better levels of measurement, the relation of their units to other units is unexplored.

Electromyography (EMG) is a nonvisual method of measuring facial activity. Several research groups have measured muscle potential changes using surface electrodes (e.g., see Fridlund \& Izard, 1983). The muscular activity detected by surface electrodes is not limited to the muscle over which the electrode is placed, making exact measurement of an active muscle difficult. Needle electrodes can measure the activity of muscle fibers more precisely than surface electrodes, but are not as convenient (Moritani \& DeVries, 1978; Sumitsuji, Matsumoto, \& Kaneko, 1965). Although EMG measurements are related to the activity of muscles, the relation between EMG and visible appearances is not known precisely. Several authors have critically analyzed the relation between visible measurement and EMG (Ekman, 1982; Fridlund \& Izard, 1983; Hager \& Ekman, 1983).

I do not attempt in this paper to translate the scalar units described in this section. Comparison of the three- to fivepoint scales indicating how much of a nominal unit is present is not very informative. Units of different physical parameters (e.g., distance, speed, electrical potential, area) cannot be translated without empirical studies. For example, a unit of area cannot easily be translated into a unit of electrical potential. It is, however, possible to investigate relationships between measurements made 
by different techniques. Ekman and Schwartz (Ekman, 1982) showed that EMG measurement of electrical potential generally correlated with FACS visible intensity scoring, but they did not try to calculate how many microvolts equal each FACS intensity score. Their study supports the validity of both measurement methods and highlights the need for a more comprehensive investigation of their correspondence. In general, the weaknesses of scalar measurements have centered around the failure to establish a correspondence between the scales and visible categorical scoring units.

\section{METHOD OF COMPARING VISUAL CATEGORICAL UNITS}

\section{Approaches to Comparing Units}

In Appendixes A and B, I compare and translate categorical units from 12 different facial measurement techniques. This translation is based on authors' own definitions of their units. Authors convey their definitions in various ways, including use of names, verbal depictions, symbols, drawings, photographs, film, and video. These definitions were compared to determine the theoretical correspondence of units from different techniques. The appendixes compare each author's conceptualization of how to unitize facial behaviors into categories; they do not compare the ways coders actually assign scores to real behaviors.

Comparing the ways coders assign actual scores would require an empirically based study. For example, reference facial behaviors might be scored independently and the different techniques and the resulting scores compared. There are many obstacles to such an empirical comparison. First, different investigators, preferably the respective authors of each technique, should train scorers, because a single investigator might train the coders to score a preconceived correspondence between units (i.e., an experimenter effect). Second, a different scorer for each technique would be necessary to prevent carry-over effects. Finding the appropriate coders would be difficult because some of the authors listed in Appendixes A and B are dead or inactive, and poor communication between laboratories might make cooperation difficult. A third problem is the selection of the reference behaviors to score. Should elementary actions, whole face gestalts, or both be selected? Should a limited set of behaviors or a set of behaviors representing each category in each technique be selected? Some techniques were designed for still photos, others for film and video, and others for naturalistic studies in real time; which technique should be used? The fourth problem is how to equate the resulting scores. Techniques might contain no units for the behavior scored, an imperfect match, or a unit that fits the behavior exactly. How should coders' attempts to make inexact matches be accommodated? How should scores be matched when one score represents only part of a configuration and another score for the same behavior represents the whole configuration? If motion records are used, how do researchers deal with different approaches to segmenting the flow of behavior into units? Should scorers be allowed to use stopped and slowed motion or must they score in real time only? These are only some of the problems in designing a good empirical comparison.

Although an empirical comparison of categorical units would be difficult, it might be worth the effort because it answers different questions than those answered by the comparison of definitions presented here. Comparing the definitions of units shows the conceptual correspondence of units, free from the errors and problems introduced by the practical considerations of coding. This comparison can help answer these questions: whether problems or gaps exist in an author's unitization of behavior; whether the units comprehensively cover possible behaviors; and whether the technique measures behaviors that are relevant to an investigator's concepts. An empirical comparison, on the other hand, addresses questions about the convergent validity of different measurement systems and relative accuracy, sensitivity, or reliability of techniques. If the empirical study were able to overcome the obstacles noted above, an empirical comparison also might help to assess how well the conceptual comparison of definitions presented here holds up in practical applications. Other approaches to validating a comparison of definitions are discussed below.

My approach to comparing units based on definitions also faces some difficulties. This comparison relies on the quality of definitions, but quality varies across techniques. Sometimes, little more information than names and shorthand symbols of units are given (e.g., Birdwhistell, 1970; Frois-Wittmann, 1930). Other authors add short verbal descriptions of each unit (e.g., Kendon \& Ex, 1969; Landis, 1924; Nystrom, 1974). The units of many techniques, however, are described in detail and illustrated with photographs (e.g., McGrew, 1972), drawings (Blurton-Jones, 1971; Brannigan \& Humphries, 1972), and even film (Ekman \& Friesen, 1978) or videotape segments (Izard, 1983). In making the translations of units, all the available information, such as written descriptions, pictures, and drawings, have been used to determine the equivalence of units. The more information used to define units, the better the basis for comparison and the more accurate the translation.

Comparing categorical units can be difficult also because authors do not agree on what features of behaviors to include in their definitions. A unit of one technique can be a compound of more elementary components that are separate units in another technique. Similarly, some units [such as "medial brow nods" (Birdwhistell, 1970)] would be scored as a sequence of units in another technique [in this case a series of "brow lowering" (Ekman \& Friesen, 1978)]. Some units incorporate temporal durations into their definitions [e.g., the "eyebrow flash" (McGrew, 1972 ) which is a brief "eyebrows raised" (Blurton-Jones, 1971)]. The intensity of a unit can be a part of its definition, as in many of Young and Decarie's (1977) units, or intensity can be indexed independently, as in the "op- 
tional intensity scoring" of Ekman and Friesen's FACS (1978). When intensity is a part of the definition of units, the number of units spanning the range of intensities of the same behavior may differ among techniques. For example, Blurton-Jones (1971) specified three units for the degree of lip parting, but other authors used only one (e.g., "mouth open").

Units may or may not imply a function for facial activities. For example, the same behavior might be categorized as "intension speak" (Brannigan \& Humphries, 1972 ) that implies a language production function, or as "mouth open" (e.g., Grant, 1969) that does not. Rather than specifying only the activities of the face, units may imply a relationship to environmental objects, as do "kiss," "'bite"' (McGrew, 1972), "evade"' (Grant, 1969), and "chew" (Brannigan \& Humphries, 1972). Some units represent changes in appearance referenced either to the head or to some other standard. For example, the up-anddown direction of gaze may be relative either to the head (Blurton-Jones, 1971; Ekman \& Friesen, 1978) or to the ground (Brannigan \& Humphries, 1972; Grant, 1969). Different appearances for the same unit are common. For example, each of Young and Decarie's (1977) whole face units have many equivalent patterns that vary in detail.

\section{Procedure for Comparison}

Given the difficulties discussed above, establishing an exact correspondence among all the units of these different techniques was impossible. For the translation, one criterion was needed that could be applied to all units to establish those that correspond to each other. The muscular basis for units was chosen as this criterion because it is the only one by which all units can be compared. Using the muscular basis of units as a criterion means that some equated units differ slightly, either in subtle details of the behavior's appearance or in some other qualities of the authors' definitions of their units, such as function or duration.

The muscular basis for units was determined by "scoring" the definitions of units in terms of Ekman and Friesen's FACS. FACS was chosen because it is a commercially available measurement technique, is comprehensive in that virtually all facial muscular actions are represented, and is widely used by investigators in many laboratories. I determined the muscular basis of units from the authors' written descriptions of the appearances of the behavioral units and by examining and scoring any visual representations of the units. Authors of units often did not specify the muscular basis, but when an author explicitly specified the muscles involved, my procedure was to verify that the muscular basis was correct and corresponded to FACS's definition. Behavioral units of different techniques were equated when they described the same appearance changes and had the same muscular basis. In rare cases, a genuine disagreement surfaced about what appearance is produced by a muscular action. In such cases, the units were not equated. The most widely known disagreement is Ekman and Friesen (1978) versus
Hjortsjo (1969) about the appearances produced by risorius and buccinator.

Each technique was added to the tables one at a time. As a technique was added, the units were cross-checked with the units of the other techniques to verify the correspondence. In rare instances, an author clearly specified the wrong muscular basis for a behavior or stated an incorrect relation between a unit in his system and another's. The translation presented here tried to correct such mistakes.

\section{Validity Issues}

The translation of units presented here is valid for comparing units on their muscular basis, but not necessarily valid for comparisons based on other aspects of definitions, such as function. There are two major considerations for assessing the validity of this translation. The first is whether I am capable of reliably "scoring" the definitions of units in terms of FACS units. Several reliability studies have consistently shown me to be a reliable FACS scorer. ${ }^{2}$ This established expertise supports the accuracy of the translation. A more important consideration for assessing validity is whether the authors and users of these techniques agree on the accuracy of the appendixes. This evidence is difficult to obtain, but it will be easier now that the tables are available to a larger audience that can criticize and suggest further refinements. (Readers' comments will be incorporated into future revisions of the tables, which are available to any one who sends a request.)

Whether coders actually assign units according to the translation presented here is a separate issue. How coders assign units depends upon many factors, including how well scorers are trained. Ideally, the tables reflect how coders using a particular technique should score behaviors in respect to the other techniques.

\section{Selection of Techniques}

The techniques that are listed in the appendixes have had the most significant influence on researchers measuring the face. Many were intended for the use of other researchers, are accessible and available for others to use, and represent a broad range of approaches to measuring facial activities.

Not all techniques that used nominal units are translated in Appendixes A and B. Appendix A translates all five anatomically based techniques listed by Ekman (1982). No other anatomical measurement method was added because the actions included or subjects studied were limited in some way, as described below. In addition to these five measurement techniques, Appendix A includes Hjortsjo's (1969) list of muscular actions involved in facial expression. Hjortsojo did not develop a measurement technique, but he studied how the activity of particular muscles was related to certain emotion expressions. His list of muscle actions is important because it helped other researchers, such as Ekman and Friesen (1976) and Ermiane and Gergerian (1978), to formulate their measurement systems. 
Hjortsjo's list of actions involved in emotion expressions is presented in Table 1.

Appendix B includes six of the other nine techniques compared by Ekman (1982). The method developed by Young and Decarie (1977) is omitted because their units describe the whole face and have many variations, making it difficult to fit their categories into the table. The method of Ekman, Friesen, and Tomkins (1971) is omitted for similar reasons. Each of their units describes an area of the face (forehead, eyes and eyelids, or lower face) and is defined by pictures. This approach was replaced by FACS. Nystrom's (1974) technique is omitted because he studied only the movements of sleeping neonates. This limitation gave rise to many unique units, such as "sucking on pacifier," "blinking under shut lids," and "vomiting," and relatively fewer units applicable to an older, awake population. Izard et al.'s Affex (1983) is included in parentheses under Izard's column to indicate the MAX units that are relevant to Affex units.

There are several reasons for excluding other techniques. Some were not translated because the range of behaviors they measure is too limited. For example, Washburn (1929) and Thompson (1941) measured only the components of laughing, smiling, and crying in infants; Gilmer (1933), like Nystrom (1974), cataloged only appearances of neonates; Jecker, Maccoby, and Breitrose (1965) coded only movements related to the comprehension of a lecture; Leventhal and Sharp (1965) identified only movements indicating comfort or distress. Other techniques have limited availability and/or have been used too infrequently to warrant translation (e.g., Ekman et al., 1971; Kendon \& Ex, 1969; Vine, 1971; Young and Decarie, 1977; Seaford, 1976). Finally, techniques not written in English (e.g., Lersch, 1932/1971) were excluded because language barriers are an additional problem for adequate translation.

\section{USING THE APPENDIXES}

Appendix A translates units of techniques that measure facial expressions with elementary components of behaviors. The anatomical basis for facial behaviors was one important consideration that authors used to construct these techniques. Appendix B translates units of techniques in which function or the theoretical importance of behaviors was given more weight than anatomy in deriving units. The columns of these appendixes list the units of each technique; the rows contain equivalent units.

\section{General}

In both appendixes, units are translated into the units of Ekman and Friesen's FACS, which thus serves as a "reference standard." FACS represents units as numbers to minimize scoring biases and to serve as a shorthand. Verbal descriptions of these units in numerical order are found in Appendix A along with the muscular basis. Figure 1 shows the action of most FACS units schematically.

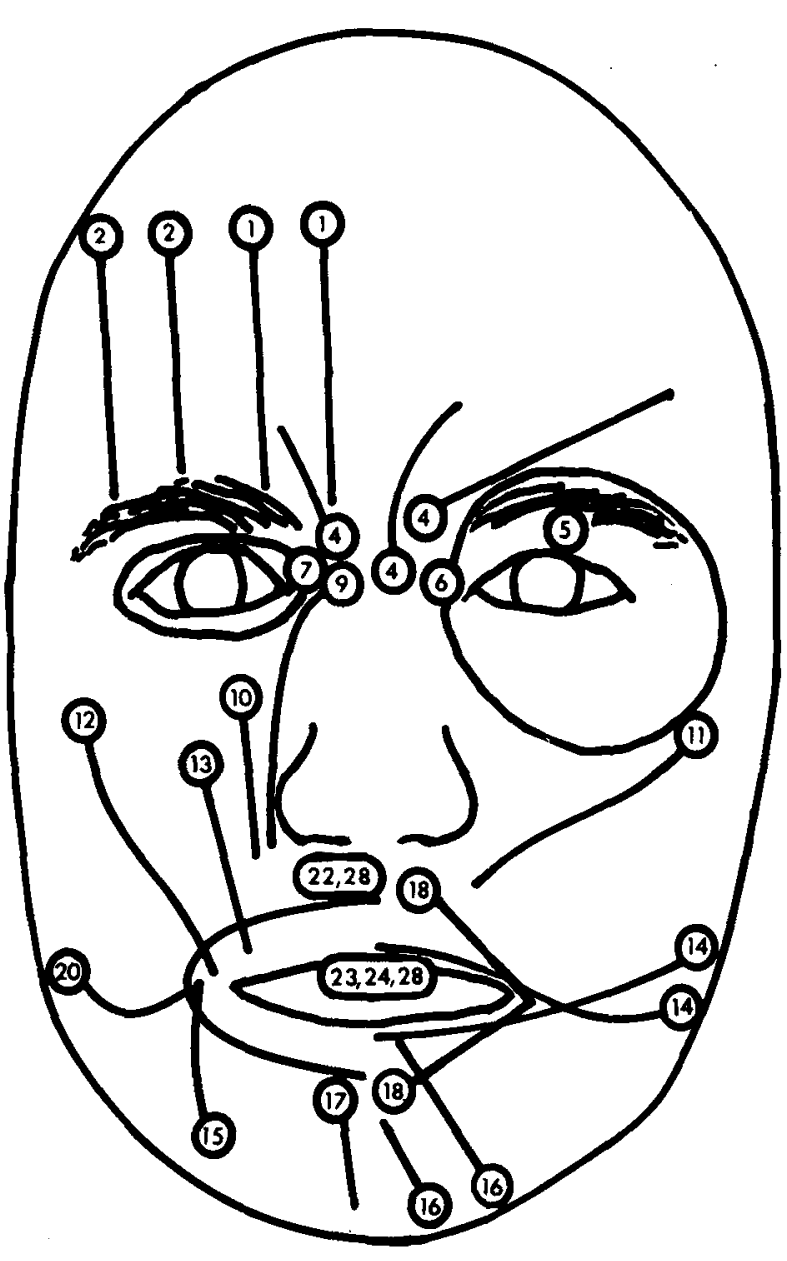

Figure 1. Schematic portrayal of FACS measurement units. Many Action Units in Ekman and Friesen's Facial Action Coding System (FACS) are depicted schematically. The number in the circle indicates the Action Unit. The circle represents a relatively fixed point towards which the skin is pulled along the radiating line.

To decode the FACS numerical representation in Appendix B, the reader should consult Appendix A and Figure 1.

Special characters in the tables facilitate comparison of units. An entry of dashes (----) indicates that there is no unit in the technique that corresponds to the units of other techniques listed in that row. The number of these blank entries in each column can provide a rough index of the comprehensiveness of a technique (i.e., the number of different behaviors that can be scored). For example, in Appendix A, Ekman and Friesen's FACS includes the greatest number of units that describe molar activities of the face and head involving muscles besides facial muscles; these activities include "cheek suck," "jaw thrust," and "crosseye." Similarly, the number of blank entries in a row indicates the extent of disagreement among authors about including a unit.

A unit that was especially difficult to translate is preceded by a question mark (?) to indicate greater uncertainty that the unit represents the same behaviors as the 
other units in the row or whether it belongs in a row by itself. Many times, a behavior that is represented by a single unit in one technique is further subdivided or elaborated into several units in another technique.

An ampersand (\&) preceding a unit indicates that the unit appears in more than one row (i.e., units in another technique attempt to make finer distinctions than are represented by this unit). By noting how many ampersands each technique has, one can assess how finely the author makes distinctions among behaviors. Sometimes, an author makes fine distinctions for particular types of behaviors that other authors do not. For example, in Appendix B, Birdwhistell's (1970) technique has many units that detail different types of head shakes and nods that other authors distinguish by only one or two units.

\section{Appendix A}

The last column in Appendix A lists the muscular basis for units; however, for some muscles, such as the extraocular and pterygoid muscles, only the general basis is indicated. Alternative names for muscles appear in parentheses. By comparing units preceded by an ampersand with the muscular basis of appearances, one can see how each technique distinguished different appearances produced by actions of the same muscle or combined the actions of more than one muscle into a single unit. For example, most techniques in Appendix A combined the actions of procerus, corrugator, and depressor supercilii into one unit representing the brows lowering together, but Hjortsjo (1969) distinguished the appearances produced by each of these different muscles. Ermiane and Gergerian (1978) distinguished the lowering from the drawing together of the brow.

Appendix A shows that different authors devised many of the same units, reflecting a general agreement about the structure of facial muscles and the appearances they produce. Disagreements arise occasionally in regard to the correspondence of fibers to units. For example, Landis (1924) and Frois-Wittmann (1930) divide the effects of orbicularis oculis into upper and lower units, but Ermiane and Gergerian (1978) and Ekman and Friesen (1978) divide the action of this muscle into inner and outer units.

Appendix A does not attempt to list the possible combinations of elementary units listed in the table. Ekman and Friesen (1978) note that combinations of units do not always produce appearances that are simple additions of the appearances of the individual units. Instead, the appearance changes that one muscle fiber produces depends complexly upon the other fibers that contract with it, the intensity of these contractions, and other factors. FACS describes in the same detail as individual actions those combinations of actions that produce distinctive appearances, but most of the combinations are not listed in Appendix A. Ekman and Friesen also give explicit rules about how the individual actions can be combined, but other authors do not. Thus, although it is possible to compare individual units in Appendix A and the few combinations that authors made explicit, it is not possible to compare how the units in different techniques might be used to represent other complex patterns of behavior.

\section{Appendix B}

For convenience, Appendix B is divided into four sections: gaze direction, the eyes, and eyelids; the brow and forehead; the cheeks and mouth; and the face or head as a whole. Each unit is listed once in Appendix B even though, occasionally, a unit may represent a change in an adjacent area of the face. The units in Appendix B are translated into terms of Ekman and Friesen's FACS. Because FACS has units only for behaviors that are the result of striated muscular action, this translation was incomplete if a unit included nonmovement activity, such as "blushing" and "tears." FACS also does not include units for some purely descriptive aspects of facial appearances such as the amount of teeth showing. The FACS scoring given is the best representation, but may not be the only one possible.

Many rows of Appendix B have more than one FACS translation because the behavioral units in the row could be produced by alternative muscular actions. Multiple FACS scores in one row indicate the failure of authors to make sharp distinctions about similar appearances that are produced by different muscular actions. For example, Blurton-Jones (1971) describes his "lips retracted" unit as a "lateral retraction of the mouth corners without raising the corner" and attributes these changes to various combinations of zygomatic major, risorius, and levator labii superioris. The decision to include different muscular actions in one unit can obscure possible differences in the significance of these actions (Seaford, 1976). Each of these muscular actions are indicative of different emotions (see Table 1).

Because the units in Appendix B (except for FACS) were derived, in part, from a consideration of their apparent importance or value, the appendix shows how consistently a behavior has been identified as meaningful. For example, all techniques have a category for nose wrinkling, but only one has categories for whether the upper or lower teeth show more. Apparently, nose wrinkling has been identified more often as a meaningful sign than has the extent that teeth show. When interpreting such conclusions, however, possible historical biases and the development of new research questions and measurement units should be considered as possible contributors to the relative number of units.

Although a unit in Appendix B may not have an equivalent unit in another technique, it might be possible to combine other units to equal the missing unit. Further study of the units and the rules for combining them, if any, is required to understand the full range of behaviors that can be represented by each technique. For example, Brannigan and Humphries's list (1972) contains two types of smiles that do not appear in other lists, but it is possible that their "compressed smile" could be represented by combining Grant's two categories "tight lips" and "simple smile." This problem of lack of rules for com- 
bination of units and the descriptions of appearances they produce is similar to the problem with units in Appendix A.

\section{Example}

To illustrate how Appendixes A and B can be used, consider an investigator trying to analyze facial expressions to measure emotion. Table 1 lists the key facial behaviors for identifying six emotions according to four authorities. ${ }^{3}$ The term "key behaviors" refers to those units that must be measured to identify a particular emotion. An obvious use for the appendixes is to translate the units in Table 1 into their muscular basis or one common system of units. With this approach, the differences and agreements about key behaviors that each authority associates with a particular emotion can be assessed. Doing this, one sees many apparent differences about the key units for particular emotions, as well as considerable overlap. For example, three of the four authorities agree that action of the inner and outer frontalis plus corrugator is a key behavior for identifying fear. Ermiane and Gergerian (1978) agree about inner frontalis and corrugator but relegate action of the outer frontalis to an "auxiliary component." There is further disagreement about key behaviors in the mouth area for identifying fear. Friesen and Ekman agree with Izard that the action of risorius stretching lip corners laterally is a key. The other two authorities omit this action and add others not considered essential by the first two, indicating instead that lateral stretching is not a key in fear.

One question our hypothetical investigator might ask is why one investigator considers a behavior as a key to emotion when it is not so identified by other authorities. Of course, there are many possible reasons for such disagreements, including different definitions of the emotion, but one possibility can be assessed by examining Appendixes $A$ and $B$. Could it be that differences in determining key behaviors arise because the behaviors are not identified as scoring units by some authorities? Indeed, Izard's MAX omits several scoring units found elsewhere in Table 1 (e.g., zygomatic minor, compressor naris). The other techniques omit a few units found elsewhere (e.g., depressor septi is a separate unit only in Ermiane and Gergerian's HANEST and is one of their keys for anger) or construe muscular actions differently (e.g., only HANEST scores the preseptalis, a key unit in fear for these authorities, as a separate unit). We conclude that missing scoring units for behaviors can contribute to disagreements over key emotion behaviors, at least for some units.

This approach of comparing the scoring units which appear in different techniques can be extended beyond $\mathrm{Ta}$ ble 1 to help us understand the results of previous studies. For example, Landis (1924) elicited emotions with several different and inventive situations, but he concluded that no facial expression was typical of any one situation and that expressions could not distinguish emotions. There are many reasons why Landis could not distinguish situations by facial expression, including the possibility that more than one emotion was elicited by the same situation (see
Ekman et al., 1982), but omissions of emotionally relevant scoring units is a possibility that can be checked with the appendixes. Table 1 confirms the importance of Ekman's (1979) distinctions for detecting fear, sadness, and surprise (discussed earlier) by studying the raising of the inner versus outer brow in combination with drawing together and pulling down. Landis did not have separate scoring units for the inner and outer brow raises. This omission and others might have contributed to his failure to distinguish emotions.

Translating units can help to interpret previously published research. Suppose, for example, that our investigator wants to know the emotional significance of the behaviors cataloged by the ethologists in Appendix B [i.e., Blurton-Jones (1971), Brannigan \& Humphries (1972), Grant (1969), McGrew (1972)]. The investigator can look up these units in Appendix B, note the FACS equivalents, and find the emotional meanings in the EMFACS dictionary (of which Table 1 is a skeleton).

\section{SUMMARY}

The discussion of visual units for measuring facial behaviors and the translation presented here provide a necessary beginning for understanding the relationships between units of different techniques. Knowing more about the relation of coders's typical use of units to the conceptual relations specified here would provide answers to additional questions, but the necessary empirical studies are difficult. The present translation is useful for comparing the varied ways that authors of techniques conceptualize behaviors, for facilitating communications between investigators, for exploring the meanings of units of one technique in terms of others, for interpreting previous research, and for providing a basis for further refinement and clarification of this translation. Ultimately, this effort may result in a more standard and comprehensive approach to facial measurement.

\section{REFERENCES}

BirDWHISTELL, R. L. (1970). Kinesics and context. Philadelphia: University of Pennsylvania.

Blurton-Jones, N. G. (1971). Criteria for use in describing facial expressions of children. Human Biology, 41, 365-413.

BRANNigan, C. R., \& Humphries, D. A. (1972). Human non-verbal behavior, a means of communication. In N. Blurton-Jones (Ed.), Ethological studies of child behavior. Cambridge: Cambridge University Press.

DARWIN, C. (1872). The expression of the emotions in man and animals. London: John Murray.

Ekman, P. (1978). Facial signs: Facts, fantasies, and possibilities. In T. A. Sebeok (Ed.), Human ethology. Cambridge: Cambridge University Press.

Exman, P. (1979). About brows: Emotional and conversational signals. In J. Aschoff, M. von Cranach, K. Foppa, W. Lepenies, \& D. Ploog (Eds.), Human ethology. Cambridge: Cambridge University Press.

Ekman, P. (1982). Methods for measuring facial action. In K. Scherer \& P. Ekman (Eds.), Handbook of methods in nonverbal behavior research. Cambridge: Cambridge University Press. 
EkMan, P., \& Friesen, W. V. (1976). Measuring facial movement. Environmental Psychology \& Nonverbal Behavior, 1, 56-75.

EKMAN, P., \& FRIESEN, W. V. (1978). The facial action coding system. Palo Alto, CA: Consulting Psychologists Press.

Ekman, P., Friesen, W. V., \& ANColi, S. (1980). Facial signs of emotional experience. Journal of Personality \& Social Psychology, 39, 1125-1134.

Ekman, P., Friesen, W. V., \& Ellsworth, P. (1982). Research Foundations. In P. Ekman (Ed.), Emotion in the human face. Cambridge: Cambridge University Press.

Ekman, P., Friesen, W. V., \& Tomkins, S. S. (1971). Facial affect scoring technique: A first validity study. Semiotica, 3, 37-58.

EKman, P., RoPer, G., \& HAGER, J. C. (1980). Deliberate facial movement. Child Development, 51, 886-891.

Ermiane, R., \& Gergerian, R. (1978). Album des expressions $d u$ visage. Paris: la pensee universelle.

Fridlund, A. J., EkMAN, P., \& OSTER, H. (1985). Facial expressions of emotion: Review of literature, 1970-1983. In A. Siegman (Ed.), Nonverbal behavior and communications: A functional perspective. Hillsdale, NJ: Erlbaum.

Fridlund, A., \& IZARD, C. E. (1983). Electromyographic studies of facial expressions of emotions and patterns of emotions. In J. T. Cacioppo \& R. E. Petty (Eds.), Social psychophysiology. New York: Guilford.

Friesen, W. V., \& EkMAN, P. (1984). EMFACS-7. Unpublished manuscript. Human Interaction Laboratory, University of California, San Francisco.

Frois-WittMan, J. (1930). The judgment of facial expression. Journal of Experimental Psychology, 13, 113-151.

FULCHER, J. S. (1942). Voluntary facial expression in blind and seeing children. Archives of Psychology, 38, No. 272.

GILMER, B. voN H. (1933). An analysis of the spontaneous responses of the newborn infant. Journal of Genetic Psychology, 42, 392-405.

GotTMAN, J. M. (1981). Time series analysis: A comprehensive introduction for social scientists. New York: Cambridge University Press. Grant, E. C. (1969). Human facial expression. Man, 4, 525-536.

HAGER, J. C., \& EKMAN, P. (1983). The inner and outer meanings of facial expressions. In J. T. Cacioppo \& R. E. Petty (Eds.), Social Psychophysiology. New York: Guilford.

HAGER, J. C., \& EKMAN, P. (1985). The asymmetry of facial actions is inconsistent with models of hemispheric specialization. Psychophysiology, 22, 307-318.

HJORTsı, C. H. (1969). Man's face and mimic language. Lund, Sweden: Studentlitteratur.

IZARD, C. E. (1983). The maximally discriminative facial movement coding system. Newark, DE: Instructional Resource Center, University of Delaware.

Izard, C. E., Dougherty, L. M., \& Hembree, E. A. (1983). A system for identifying affect expressions by holistic judgments (Affex). Newark, DE: Instructional Resource Center, University of Delaware.

JeCKer, J. D., MACCoBY, N., \& BreITrose, H. S. (1965). Improving accuracy in interpreting non-verbal cues of comprehension. Psychology in the Schools, 2, 239-244.

KENDON, A., \& Ex, J. (1969). A notation for facial postures and bodily position. In M. Argyle, Social interaction. New York: Atherton.

LANDIS, C. (1924). Studies of emotional reactions. II. General behavior and facial expression. Joumal of Comparative Psychology, 4, 447-509.

Lersch, P. (1971). Gesicht und Seele. München: Ernst Reinhardt. (First published 1932).

LeVenthal, H., \& Sharp, E. (1965). Facial expressions as indicators of distress. In S. S. Tomkins \& C. E. Izard (Eds.), Affect, cognition, and personality. New York: Springer.

LYNN, J. G. (1940). An apparatus and method for stimulating, recording and measuring facial behavior. Journal of Experimental Psychology, 27, 81-88.

MCGREW, W. C. (1972). An ethological study of children's behavior. New York: Academic.

Moritani, T., DEVRIEs, H. A. (1978). Reexamination of the relationship between the surface integrated electromyogram (IEMG) and the force of isometric contraction. American Journal of Physical Medicine, 78, 263-277.
Nunnally, J. C. (1967). Psychometric theory. New York: McGraw-Hill.

Nystrom, M. (1974). Neonatal facial-postural patterning during sleep. I. Description and reliability of observations: Psychological Research Bulletin, 14(7), 1-16.

PARKe, F. I. (1975). Computer animation using parametric models. SPIE, 59, 20-21.

Platt, S. M., \& Badler, N. I. (1981). Animating facial expressions. Computer Graphics (USA), 15(3), 245-252.

Rosenthal, R. (1982). Conducting judgment studies. In K. Scherer \& P. Ekman (Eds.), Handbook of methods in nonverbal behavior research. Cambridge: Cambridge University Press.

Rubenstern, L. (1969). Facial expressions: An objective method in the quantitative evaluation of emotional change. Behavioral Research Methods \& Instrumentation, 1, 305-306.

Schwartz, G. E., Ahern, G. L., \& Brown, S. (1979). Lateralized facial muscle response to positive and negative emotional stimuli. Psychophysiology, 16, 561-571.

SEAFORD, H. W. (1976, November). Maximizing replicability in describing facial behavior. Paper presented at the meeting of the American Anthropological Association, Washington, D. C.

SHOR, R. E. (1978). The production and judgment of smile magnitude. Journal of General Psychology, 98, 79-96.

Sumitsui, N., Matsumoto, K., \& KaneKo, Z. (1965). A new method to study facial expression using electromyography. Electromyography, 5, 269-272.

THOMPson, J. (1941). Development of facial expression of emotion in blind and seeing children. Archives of Psychology, 37, No. 264.

Todd, J. T., Mark, L. S., Shaw, R. E., \& Pittenger, J. B. (1980). The perception of human growth. Scientific American, 242, 132-144.

Tomkins, S. S. (1962). Affect, Imagery, Consciousness. New York: Springer.

Tomkins, S. S., \& McCarTer, R. (1964). What and where are the primary affects? Some evidence for a theory. Perceptual and Motor Skills, 18, 119-158.

VINE, I. (1971). Communication by facial-visual signals. In J. H. Crook (Ed.), Social behavior in animals and man. New York and London: Academic.

WASHBURN, R. W. (1929). A study of the smiling and laughing of infants in the first year of life. Genetic Psychology Monographs, 6 , 397-537.

Wolff, H. A., Smith, C. E., \& Murray, H. A. (1934). The psychology of humor. 1. A study of responses to race-disparagement jokes. Journal of Abnormal \& Social Psychology, 28, 341-365.

Young, G., \& DeCarie, T. G. (1977). An ethology-based catalogue of facial/vocal behavior in infancy. Animal Behavior, 25, 95-107.

\section{NOTES}

1. Although this discussion emphasizes visual scoring by a trained observer, recent advances in computer simulations suggest that it may be possible to score facial movements automatically by computer, substituting pattern recognition intelligence for human vision. As a first step, some computer scientists have been able to create artificial faces and simulate muscular action in them (Parke, 1975; Platt \& Badler, 1981). While computer scoring might be more automatic and objective, the human visual system and brain will probably remain a superior alternative for the foreseeable future. Computer recognition might be employed initially when only a limited range of specific behaviors must be measured.

2. My FACS Final Test score was 87 , indicating high reliability. I have produced reliable FACS-based scores in several empirical studies including Ekman, Friesen, \& Ancoli (1980), Ekman et al. (1982), Ekman, Roper, \& Hager (1980), and Hager \& Ekman (1985).

3. Table 1 is not to be used to interpret emotion from facial behaviors. None of the complexities and rules for identifying emotions are included in this table. Specifically, this table does not include all emotions, all combinations of units that predict emotion, the effects of intensity on predictions, blends of emotion, and felt-versus-simulated or controlledversus-uncontrolled distinctions. 
APPENDIX A

Elementary Components of Facial Behaviors

\begin{tabular}{|c|c|c|c|c|c|c|}
\hline \multirow[b]{2}{*}{$\begin{array}{l}\text { Landis } \\
\text { (1924) }\end{array}$} & \multirow[b]{2}{*}{$\begin{array}{l}\text { Frois-Wittmann } \\
(1930)\end{array}$} & \multirow[b]{2}{*}{$\begin{array}{l}\text { Fulcher } \\
\text { (1942) }\end{array}$} & \multirow[b]{2}{*}{$\begin{array}{l}\text { Hjortsjo } \\
(1969)\end{array}$} & \multirow[b]{2}{*}{$\begin{array}{l}\text { Ermiane \& } \\
\text { Gergerian (1978) }\end{array}$} & \multicolumn{2}{|c|}{ Reference } \\
\hline & & & & & $\begin{array}{l}\text { Ekman \& } \\
\text { Friesen }(1978)^{*}\end{array}$ & $\begin{array}{l}\text { muscular } \\
\text { basis** }\end{array}$ \\
\hline ---- & $-\cdots$ & $-\cdots$ & $\begin{array}{l}1 \text { medial part } \\
\text { frontalis }\end{array}$ & 1 frontalis & $\begin{array}{l}1 \text { inner brow } \\
\text { raise }\end{array}$ & " pars medialis \\
\hline \&corrugators & \&brow frowning & ---- & $\begin{array}{l}3 \text { glabella } \\
\text { depressor }\end{array}$ & $\begin{array}{l}\& 4 \text { depressor } \\
\text { supercilii }\end{array}$ & \&4 brow lowerer & $\begin{array}{l}\text { procerus (pyra- } \\
\text { midalis nasi) }\end{array}$ \\
\hline \&corrugators & \&brow frowning & ----- & $\begin{array}{l}5 \text { eyebrow } \\
\text { depressor }\end{array}$ & $\begin{array}{l}\text { \&4 depressor } \\
\text { supercilii }\end{array}$ & $\& 4$ brow lowerer & $\begin{array}{l}\text { depressor } \\
\text { supercilii }\end{array}$ \\
\hline \&corrugators & \&brow frowning & corrugator & $\begin{array}{l}4 \text { eyebrow } \\
\text { wrinkler }\end{array}$ & $\begin{array}{l}3 \text { corrugator } \\
\text { supercilii }\end{array}$ & $\& 4$ brow lowerer & $\begin{array}{l}\text { corrugator } \\
\text { supercilii }\end{array}$ \\
\hline ----- & ----- & ----- & $\cdots$ & $\begin{array}{l}5 \text { auricularis } \\
\text { posterior }\end{array}$ & ---- & $\begin{array}{l}\text { auricularis } \\
\text { posterior }\end{array}$ \\
\hline eyes wide & $\begin{array}{l}\text { upper lid } \\
\text { raised }\end{array}$ & $\begin{array}{l}\text { eyes } \\
\text { widened }\end{array}$ & ----- & $\begin{array}{l}6 \text { levator palpe- } \\
\text { brae superioris }\end{array}$ & $\begin{array}{l}5 \text { upper lid } \\
\text { raise }\end{array}$ & $\begin{array}{l}\text { levator palpe- } \\
\text { brae superioris }\end{array}$ \\
\hline ----- & $-\cdots$ & $\begin{array}{l}\text { orbicularis } \\
\text { oculi }\end{array}$ & $\begin{aligned} & 6+7 \text { sphincter } \\
& \text { muscle of } \\
& \text { the eye }\end{aligned}$ & --- & 6 or $6+7$ & $\begin{array}{l}\text { orbicularis } \\
\text { oculi }(0.0 .)\end{array}$ \\
\hline$\cdots$ & --- & ---- & $\begin{array}{l}6 \text { orbital } \\
\text { part }\end{array}$ & 10 orbitalis & 6 cheek raise & $\begin{array}{l}0.0 . \text { pars } \\
\text { orbitalis }\end{array}$ \\
\hline ----- & ---- & ---- & 7 eyelid part & $\begin{array}{l}\& 9 \text { palpebralis } \\
\text { inferioris: } \\
\text { winking }\end{array}$ & 7 lids tight & $\begin{array}{l}0.0 . \text { pars } \\
\text { palprebralis }\end{array}$ \\
\hline $\begin{array}{l}\text { upper orbicu- } \\
\text { laris oculis }\end{array}$ & $\begin{array}{l}\text { upper lid } \\
\text { depressed }\end{array}$ & ---- & --- & $\begin{array}{l}8 \text { palpebralis } \\
\text { superioris }\end{array}$ & ---- & $\begin{array}{l}0.0 . \text { pars } \\
\text { superioris }\end{array}$ \\
\hline $\begin{array}{l}\text { \&lower orbicu- } \\
\text { laris oculi }\end{array}$ & $\begin{array}{l}\text { \&lower lid } \\
\text { wrinkled }\end{array}$ & $-\cdots$ & $-\cdots$ & 11 preseptalis & $\cdots$ & preseptalis \\
\hline $\begin{array}{l}\text { \&lower orbicu- } \\
\text { laris oculi }\end{array}$ & $\begin{array}{c}\text { \&lower lid } \\
\text { wrinkled }\end{array}$ & ---- & ---- & 7 pretarsalis & ---- & pretarsalis \\
\hline 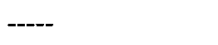 & ----- = & ---- & $\cdots$ & $\cdots+-$ & 8 lips toward & orbicularis oris \\
\hline $\begin{array}{l}\text { \&quadratus } \\
\text { labii } \\
\text { superioris }\end{array}$ & nose wrinkled & $\begin{array}{l}\text { \&quadratus } \\
\text { labii } \\
\text { superioris }\end{array}$ & $\begin{array}{l}9 \text { upper lip and } \\
\text { nasal wing } \\
\text { levator }\end{array}$ & $\begin{array}{l}15 \text { levator labii } \\
\text { superioris, } \\
\text { alaque nasi }\end{array}$ & 9 nose wrinkle & $\begin{array}{l}\text { levator labii } \\
\text { superioris, } \\
\text { alaque nasi }\end{array}$ \\
\hline $\begin{array}{l}\text { \&quadratus labii } \\
\text { superioris }\end{array}$ & $\begin{array}{l}\text { upper lip } \\
\text { raised }\end{array}$ & $\begin{array}{l}\text { \&zquadratus } \\
\text { labiu } \\
\text { superioris }\end{array}$ & $\begin{array}{l}10 \text { upper lip } \\
\text { levator }\end{array}$ & $\begin{array}{l}16 \text { levator labii } \\
\text { superioris }\end{array}$ & $\begin{array}{l}10 \text { upper lip } \\
\text { raise }\end{array}$ & $\begin{array}{l}\text { levator labii } \\
\text { superioris }\end{array}$ \\
\hline ---- & $\begin{array}{l}\text { upper lip } \\
\text { depressed }\end{array}$ & ----- = = & $-\cdots$ & $\begin{array}{l}14 \text { depressor } \\
\text { septi }\end{array}$ & ----- & $\begin{array}{l}\text { depressor } \\
\text { septi }\end{array}$ \\
\hline \&zygomaticus & \&corners raised & \&zygomaticus & $\begin{array}{l}11 \text { lesser } \\
\text { zygomatic } \\
\text { muscle }\end{array}$ & $\begin{array}{l}17 \text { zygomaticus } \\
\text { minor }\end{array}$ & $\begin{array}{l}11 \text { nasolabial } \\
\text { deepen }\end{array}$ & zygomatic minor \\
\hline \&zygomaticus & \&corners raised & $\begin{array}{l}\text { \&zygomaticus } \\
\text { (or lips } \\
\text { smiling) }\end{array}$ & $\begin{array}{l}12 \text { greater } \\
\text { zygomatic } \\
\text { muscle }\end{array}$ & $\begin{array}{l}18 \text { zygomaticus } \\
\text { major }\end{array}$ & $\begin{array}{l}12 \text { lip corner } \\
\text { pull }\end{array}$ & zygomatic major \\
\hline$-\cdots$ & $\cdots$ & $\cdots$ & $\begin{array}{l}13 \text { levator of } \\
\text { the angle of } \\
\text { the mouth }\end{array}$ & 22 caninus & 13 cheek puff & $\begin{array}{l}\text { caninus (levator } \\
\text { anguli oris) }\end{array}$ \\
\hline ---- & $-\cdots$ & ----- & $\begin{array}{l}14 \text { smiling } \\
\text { muscle }\end{array}$ & --- & $\cdots$ & risorius \\
\hline--- & ---- & ---- & $\cdots-$ & 19 buccinator & 14 dimpler & buccinator \\
\hline triangularis & $\begin{array}{l}\text { corners } \\
\text { depressed }\end{array}$ & triangularis & $\begin{array}{l}15 \text { depressor of } \\
\text { the angle of } \\
\text { the mouth }\end{array}$ & 23 triangularis & 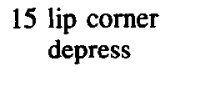 & $\begin{array}{l}\text { triangularis } \\
\text { (depressor anguli } \\
\text { oris) }\end{array}$ \\
\hline
\end{tabular}


APPENDIX A (continued)

\begin{tabular}{|c|c|c|c|c|c|c|}
\hline \multirow[b]{2}{*}{$\begin{array}{l}\text { Landis } \\
(1924) \\
\end{array}$} & \multirow[b]{2}{*}{$\begin{array}{l}\text { Frois-Wittmann } \\
(1930)\end{array}$} & \multirow[b]{2}{*}{$\begin{array}{l}\text { Fulcher } \\
(1942)\end{array}$} & \multirow[b]{2}{*}{$\begin{array}{l}\text { Hjortsjo } \\
(1969) \\
\end{array}$} & \multirow[b]{2}{*}{$\begin{array}{l}\text { Ermiane \& } \\
\text { Gergerian (1978) }\end{array}$} & \multicolumn{2}{|c|}{ Reference } \\
\hline & & & & & $\begin{array}{l}\text { Ekman \& } \\
\text { Friesen }(1978)^{*}\end{array}$ & $\begin{array}{l}\text { muscular } \\
\text { basis** }\end{array}$ \\
\hline$\cdot$ & & & & & & \\
\hline ----- & $\begin{array}{l}\text { lower lip } \\
\text { raised }\end{array}$ & ----- & ---- & ---- & $-\cdots--$ & $\begin{array}{l}\text { orbicularis oris } \\
\text { or mentalis }\end{array}$ \\
\hline mentalis & chin raised & ---- & 17 chin muscle & 27 mentalis & 17 chin raise & mentalis \\
\hline ---- & ---- & $\cdots$ & $\begin{array}{l}18+19 \text { incisive } \\
\text { muscles of } \\
\text { the upper } \\
\text { and lower } \\
\text { lip }\end{array}$ & 24 incisivus & 18 lip pucker & incisivi labii \\
\hline ----: & ---- & ---. & ---- ～～～～～～ & -..-- & 19 tongue show & not specific*** \\
\hline ---- & $\cdots$ & ---- & $\begin{array}{r}20+21 \text { cheek } \\
\text { muscle }\end{array}$ & $--\cdot-$ & $\cdots$ & buccinator \\
\hline risorius & $\begin{array}{l}\text { corners } \\
\text { contracted }\end{array}$ & risorius & ----- & 20 risorius & 20 lip stretch & risorius \\
\hline ----- & ----- & ---- & $\cdots$ & 21 platysma & 21 neck tighten & platysma \\
\hline $\begin{array}{l}\text { \&lips pursed or } \\
\text { compressed }\end{array}$ & ---- & lips pursed & $\begin{array}{c}22+23 \text { sphincter } \\
\text { of the } \\
\text { mouth }\end{array}$ & $\begin{array}{l}25 \text { orbicularis } \\
\text { oris }\end{array}$ & $\cdots$ & $\begin{array}{l}\text { orbicularis } \\
\text { oris }\end{array}$ \\
\hline ----- & $\begin{array}{l}\text { upper lip } \\
\text { protruding }\end{array}$ & $\cdots$ & \&22 lip part & $\cdots$ & t22 lip funnel & orbicularis oris \\
\hline$\cdots$ & $\begin{array}{l}\text { lower lip } \\
\text { protruding }\end{array}$ & ---- & $\& 22$ lip part & $-\cdots$ & b22 lip funnel & orbicularis oris \\
\hline ---- & ----- & ---- & $\begin{array}{l}23 \text { marginal } \\
\text { part }\end{array}$ & ---- & 23 lip tight & orbicularis oris \\
\hline $\begin{array}{l}\text { \&lips pursed or } \\
\text { compressed }\end{array}$ & ---- & $\begin{array}{l}\text { lips } \\
\text { compressed }\end{array}$ & $\cdots$ & --- & 24 lip press & orbicularis oris \\
\hline \&lips open & lips open & $\begin{array}{l}\text { lips just } \\
\text { parted }\end{array}$ & ---- & $---\cdot$ & 25 lips part & not specific*** \\
\hline \&lips open & ---- & \&jaw dropped & --- & $\begin{array}{l}\text { \&II-1 depression } \\
\text { of mandible }\end{array}$ & 26 jaw drop & lateral pterygoids \\
\hline$-\cdots$ & ---- & $\begin{array}{l}\text { lips wide } \\
\text { open }\end{array}$ & $-\cdots$ & 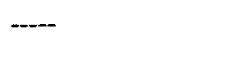 & --- & not specific**** \\
\hline ---- & $---\cdot$ & lips rounded & ---- & 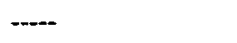 & $-\cdots$ & not specific*** \\
\hline \&lips open & --- & \&jaw dropped & ---- & $\begin{array}{l}\text { \&II-1 depression } \\
\text { of mandible }\end{array}$ & 27 mouth stretch & lateral pterygoids \\
\hline ---.. & ---- & $\cdots$ & $-\cdots$ & $\begin{array}{l}\text { II-2 elevation of } \\
\text { the mandible }\end{array}$ & $\cdots$ & $\begin{array}{l}\text { masseter, medial } \\
\text { pterygoids }\end{array}$ \\
\hline ----- & lips closed & $\cdots$ & $\ldots$ & --- & $\cdots$ & not specific**** \\
\hline -.-.- & teeth open & $\cdots$ & ---- & $\cdots$ & --- & not specific $* * *$ \\
\hline ----- & teeth closed & ---- & $-\cdots$ & ---- & $\cdots$ & not specific ${ }^{* * *}$ \\
\hline -.--- & $\begin{array}{l}\text { upper teeth } \\
\text { exposed }\end{array}$ & $\cdots$ & $\cdots$ & $-\cdots$ & $\ldots$ & not specific*** \\
\hline ---- & $\begin{array}{l}\text { lower teeth } \\
\text { exposed }\end{array}$ & --- & $\cdots$ & --- & $\cdots$ & not specific*** \\
\hline -.-- & lips retracted & $\cdots$ & 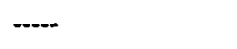 & $-\cdots$ & 28 lip suck & not specific*** \\
\hline ---- & $-\cdots$ & $\cdots$ & $\cdots$ & $\begin{array}{l}\text { II-3 protrusion } \\
\text { of the } \\
\text { mandible }\end{array}$ & 29 jaw thrust & pterygoids \\
\hline --.- & $-\cdots$ & $\cdots$ & $-\cdots$ & $\begin{array}{l}\text { II-4 retraction } \\
\text { of the } \\
\text { mandible }\end{array}$ & $\cdots$ & pterygoids \\
\hline$-\cdots$ & ---- & $\cdots$ & --- & $\begin{array}{l}\text { II-5 lateral } \\
\text { movements of } \\
\text { the mandible }\end{array}$ & $\begin{array}{l}30 \text { jaw to } \\
\text { sideways }\end{array}$ & pterygoids \\
\hline ----- & ---- & jaw clenched & ---- & $\cdots$ & 31 jaw clench & masseter \\
\hline ---- & ---- & $\cdots$ & ---- & $\cdots$ & 32 bite & not specific $* * *$ \\
\hline ---- & $\cdots$ & --- & --- & ---- & 33 blow & not specific*** \\
\hline ---- & $\cdots$ & $\cdots$ & $\cdots$ & $\cdots$ & 34 puff & not specific**** \\
\hline$\cdots$ & ----- & --- & ---- & $---\cdot$ & 35 cheek suck & not specific ${ }^{* * *}$ \\
\hline
\end{tabular}




\begin{tabular}{|c|c|c|c|c|c|c|}
\hline \multirow[b]{2}{*}{$\begin{array}{l}\text { Landis } \\
(1924)\end{array}$} & \multirow[b]{2}{*}{$\begin{array}{l}\text { Frois-Wittmann } \\
(1930)\end{array}$} & \multirow[b]{2}{*}{$\begin{array}{l}\text { Fulcher } \\
(1942)\end{array}$} & \multirow[b]{2}{*}{$\begin{array}{l}\text { Hjortsjo } \\
(1969) \\
\end{array}$} & \multirow[b]{2}{*}{$\begin{array}{l}\text { Ermiane \& } \\
\text { Gergerian (1978) }\end{array}$} & \multicolumn{2}{|c|}{ Reference } \\
\hline & & & & & $\begin{array}{l}\text { Ekman \& } \\
\text { Friesen }(1978)^{*}\end{array}$ & $\begin{array}{l}\text { muscular } \\
\text { basis** }\end{array}$ \\
\hline$\cdots$ & ---+ & ----- & $\cdots$ & ----- & 36 tongue bulge & tongue \\
\hline--- & $\cdots$ & $-\cdots$ & ---- & $\cdots$ & 37 lip wipe & tongue \\
\hline nasalis & nose dilated & ---- & $\cdots$ & 12 dilator naris & 38 nose dilate & $\begin{array}{l}\text { dilator naris } \\
\text { (nasalis, alar part) }\end{array}$ \\
\hline$\cdots$ & nose pinched & ---- & 8 nasal muscle & $\begin{array}{l}13 \text { compressor } \\
\text { naris }\end{array}$ & $\begin{array}{l}39 \text { nostril } \\
\text { compress }\end{array}$ & $\begin{array}{l}\text { compressor naris } \\
\text { (nasalis, transverse } \\
\text { part) or depressor } \\
\text { septi }\end{array}$ \\
\hline --- & $\cdots--$ & --- & ---- & ----- & 41 lid droop & $\begin{array}{l}\text { levator palpebrae } \\
\text { superioris }\end{array}$ \\
\hline \&eyes closed & ---- & ----- & ---- & ----- & 42 slit & $\begin{array}{l}\text { orbicularis } \\
\text { oculi }\end{array}$ \\
\hline \&eyes closed & ---.. & ----- & ----- & ----- & 43 closed & $\begin{array}{l}\text { orbicularis } \\
\text { oculi }\end{array}$ \\
\hline \&eyes closed & $-\cdots--$ & --- & ----- & $-\cdots$ & 44 squint & $\begin{array}{l}\text { orbicularis } \\
\text { oculi }\end{array}$ \\
\hline$\cdots$ & $-\cdots$ & ---- & $\cdots$ & --- & 45 blink & $\begin{array}{l}\text { orbicularis } \\
\text { oculi }\end{array}$ \\
\hline ----- & $-\cdots$ & ---. & ----- & ---- & 46 wink & $\begin{array}{l}\text { orbicularis } \\
\text { oculi }\end{array}$ \\
\hline \&head movements & $\cdots$ & ---- & ---- & \&III-5 rotation & 51 turn left & not specific $* * *$ \\
\hline \&head movements & ---- & ---- & $-\cdots$ & \&III-5 rotation & 52 tum right & not specific*** \\
\hline \&head movements & ---- & ---- & ---- & $\begin{array}{r}\text { III-4 backward } \\
\text { extension }\end{array}$ & 53 head up & not specific*** \\
\hline \&head movements & ---- & head down & ----- & $\begin{array}{l}\text { III-2 forward } \\
\text { flexion }\end{array}$ & 54 head down & not specific*** \\
\hline \&head movements & $-\cdots$ & $\begin{array}{r}\text { \&head to } \\
\text { the side }\end{array}$ & $-\cdots$ & $\begin{array}{l}\text { \&III-3 lateral } \\
\text { flexion }\end{array}$ & 55 tilt left & not specific*** \\
\hline \&head movements & ----- & $\begin{array}{l}\text { \&head to } \\
\text { the side }\end{array}$ & ----- & $\begin{array}{l}\text { \&III-3 lateral } \\
\text { flexion }\end{array}$ & 56 tilt right & not specific*** \\
\hline \&head movements & -..-- & ----- & ---- & III-6 propulsion & 57 forward & not specific*** \\
\hline \&head movements & head back & ---- & ---- & \&III-7 retropulsion & \&58 back & not specific*** \\
\hline chin back & $\cdots$ & $-\cdots-$ & $\cdots$ & \&III-7 retropulsion & $\& 58$ back & not specific*** \\
\hline ----- & \&glance side & --- & $\cdots$ & $* * * *$ & $\begin{array}{l}61 \text { eye position } \\
\text { left }\end{array}$ & extraocular \\
\hline ----- & \&glance side & ----- & ----- & $* * * *$ & $\begin{array}{l}62 \text { eye position } \\
\text { right }\end{array}$ & extraocular \\
\hline eyes up & ---- & $-\cdots$ & ---- & $* * * *$ & 63 eye position up & extraocular \\
\hline ---- & glance down & eyes lowered & $-\cdots$ & $* * * *$ & $\begin{array}{l}64 \text { eye position } \\
\text { down }\end{array}$ & extraocular \\
\hline -...- & ---- & ---- & ---- & $\cdots$ & walleye & extraocular \\
\hline ---- & ---- & $\cdots$ & -.-- & ---- & crosseye & extraocular \\
\hline
\end{tabular}

Note - -.-- = No equivalent unit. ? = Unit may not be equivalent to others on the same line. \& = Unit appears on more than one line. ${ }^{*} F A C S$ scores consist of an alphabetic prefix indicating asymmetry $(G$ or $H)$ and laterality $(R$ or $L)$, the number of the action unit, and an alphabetic suffix indicating intensity of the action. The $X$ suffix indicates low intensity; the $Y$ suffix, moderate intensity; the $Z$ suffix, high intensity. The $R$ prefix indicates actions only on the right side of the face; the $L$ prefix, actions only on the left. In later scoring additions, the prefixes $G$ and $H$ indicated right and left asymmetry. ${ }^{* *}$ Alternative names of muscles are given in parentheses. ***Various muscles and behaviors can produce the appearances indicated by this unit. $\quad * * *$ Ermiane and Gergerian (1978) provide a long, complex list of gaze directions, planes, and orientations. 
APPENDIX B

Empirically Derived Units for Facial Behavior

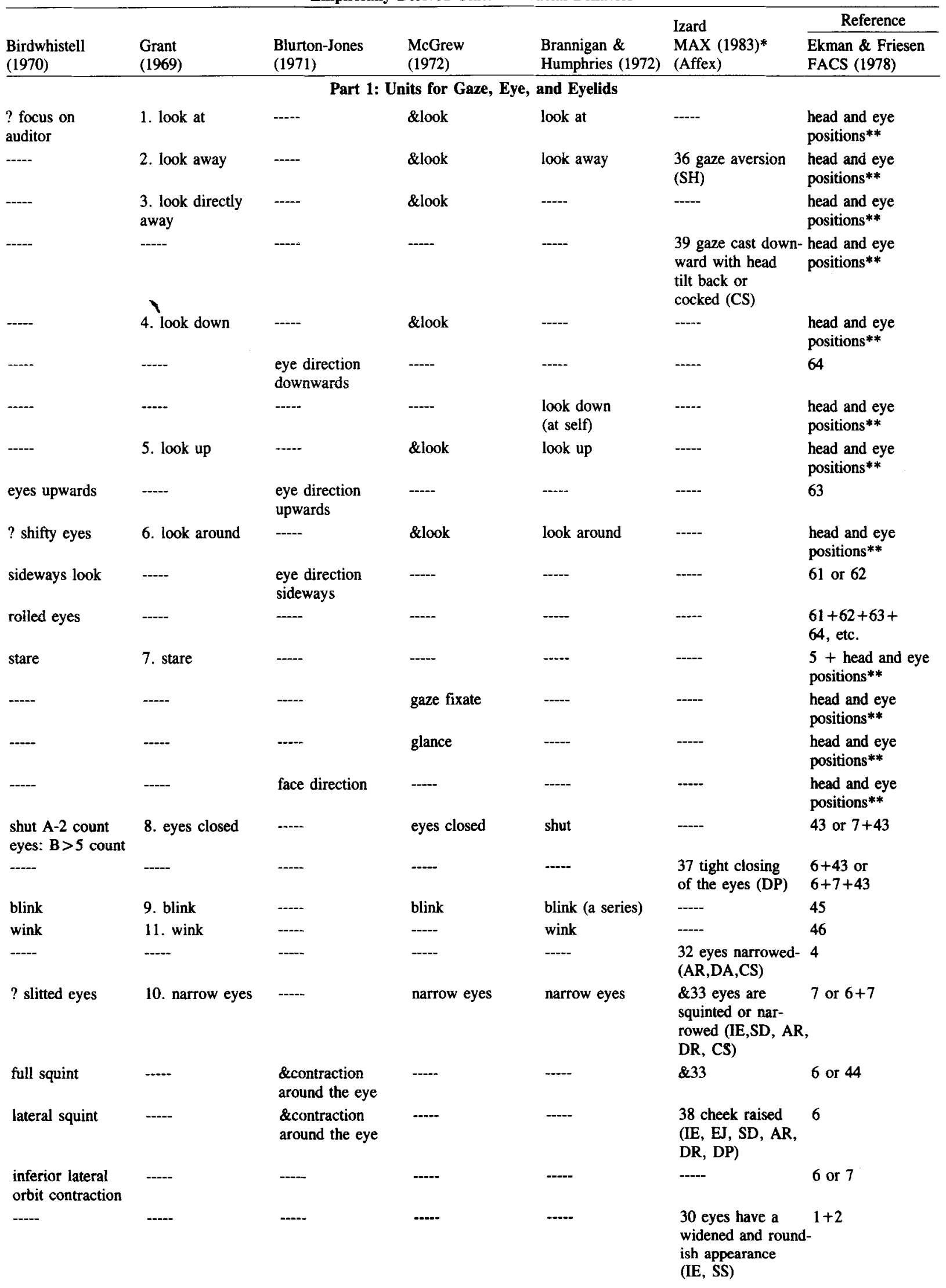


APPENDIX B (continued)

\begin{tabular}{|c|c|c|c|c|c|c|}
\hline & & & & & & Reference \\
\hline $\begin{array}{l}\text { Birdwhistell } \\
(1970)\end{array}$ & $\begin{array}{l}\text { Grant } \\
(1969)\end{array}$ & $\begin{array}{l}\text { Blurton-Jones } \\
(1971)\end{array}$ & $\begin{array}{l}\text { McGrew } \\
(1972)\end{array}$ & $\begin{array}{l}\text { Brannigan \& } \\
\text { Humphries (1972) }\end{array}$ & $\begin{array}{l}\text { MAX }(1983)^{*} \\
\text { (Affex) }\end{array}$ & $\begin{array}{l}\text { Ekman \& Friesen } \\
\text { FACS (1978) }\end{array}$ \\
\hline wide eyed & 12. eyes open & $\begin{array}{l}\text { eye openness: } \\
\text { wide }\end{array}$ & $\cdots$ & stare & $\begin{array}{l}\& 31 \text { eyes are } \\
\text { widened and more } \\
\text { white shows than } \\
\text { normal (FT) }\end{array}$ & $5 \mathrm{Y}$ or $5 Z^{* * *}$ \\
\hline ---- & -...-- & " " bit wide & ----- & ----- & $\& 31$ & $5 Y$ or $5 X^{* * *}$ \\
\hline ---- & $\cdots+. .$. & " " normal & ---- & open & ----- & ---- \\
\hline ---- & ----- & " "bit narrow & ----- & ---- & ----- & 41 \\
\hline -..-- & ----- & " " very narrow & ---- & ----- & ----- & 42 \\
\hline ----- & ---- & upper lid down & ---- & droop & $\ldots$ & 41 \\
\hline ----- & -...- & $-\cdots$ & ---- & widen & ----- & 5 (rapid) \\
\hline ---- & 13. pouch & ---- & $\cdots$ & pouch & ----- & -...- \\
\hline -...- & 14. tears & $\cdots$ & weep & tears & ----- & -..- \\
\hline$\cdots$ & 61. twitch & ---- & ---- & twitch & $\cdots$ & 6 (rapid) \\
\hline \multicolumn{7}{|c|}{ Part 2: Units in the Forehead and Brow Area } \\
\hline raised brows & $\begin{array}{l}\text { 16. eyebrows } \\
\text { raised }\end{array}$ & raised brows & ---- & raise & $\begin{array}{l}20 \text { brows are } \\
\text { raised in } \\
\text { normal shape } \\
\text { (IE, SS) }\end{array}$ & $1+2$ \\
\hline $\begin{array}{l}\text { single raised } \\
\text { brow }\end{array}$ & ---- & $\cdots$ & ---- & ---- & $\begin{array}{l}21 \text { one brow } \\
\text { raised higher than } \\
\text { the other (CS) }\end{array}$ & $\begin{array}{l}\mathrm{R} 1 \text { or } \mathrm{R} 2 \text { or } \\
\mathrm{R} 1+\mathrm{R} 2 \text { or } \mathrm{L} 1, \mathrm{~L} 2 \\
\text { or } \mathrm{L} 1+\mathrm{L} 2 * * * *\end{array}$ \\
\hline---- & 15. flash &..-- & eyebrow flash & flash & 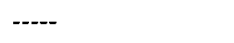 & $1+2$ (rapid) \\
\hline ---- & $-\ldots$ & $+\cdots$ & wide eyes & ---- & ----- & $1+2+5$ \\
\hline lowered brow & ---- & $-\ldots$ & $-\cdots$ & ----- & ----- & $\mathrm{R} 4$ or $\mathrm{L} 4 * * * *$ \\
\hline medial brow nods & ----- & ---- & $-\cdots$ & ----- & 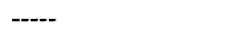 & 4 (a series) \\
\hline$---\cdot$ & $\begin{array}{l}\text { 17. aggressive } \\
\text { frown }\end{array}$ & strong frown & \&low frown & angry frown & $\begin{array}{l}25 \text { eyebrows low- } \\
\text { ered and drawn to- } \\
\text { gether (AR, DR, } \\
\text { DP) }\end{array}$ & $4 \mathrm{Y}$ or $4 \mathrm{Z}^{* * *}$ \\
\hline $\begin{array}{l}\text { ? medial brow } \\
\text { contraction }\end{array}$ & $\begin{array}{l}\text { 18. puzzled } \\
\text { frown }\end{array}$ & weak frown & \&low frown & ---- & $\begin{array}{l}24 \text { eyebrows are } \\
\text { drawn together (IE) }\end{array}$ & $4 X^{* * *}$ \\
\hline---- & ---- & ---- & ---- & ---- & $\begin{array}{l}22 \text { brows raised } \\
\text { part way but not } \\
\text { maximally, and } \\
\text { they are drawn } \\
\text { together (FT) }\end{array}$ & $1+2+4$ \\
\hline ----- & 19. sad frown & \&oblique brows & ---- & sad frown & $\begin{array}{l}23 \text { inner corners } \\
\text { of the eyebrow } \\
\text { are raised and } \\
\text { pulled medially } \\
\text { (SD) }\end{array}$ & $1+4$ or $1+4+6$ \\
\hline ---- & ----- & \&oblique brows & $\cdots$ & sad raise & ---- & 1 or $1+4$ \\
\hline$\cdots$ & ---- & $\begin{array}{l}\text { general } \\
\text { frowns }\end{array}$ & ---- & $\ldots$ & $\ldots$ & $\begin{array}{l}\text { other combi- } \\
\text { nations of AU4 }\end{array}$ \\
\hline---- & ---- & $\cdots$ & pucker face & $-\cdots--$ & -.-- & $\begin{array}{l}1+4+(6 \text { or } 44) \\
\text { or } 1+4+9+44 \\
\text { may include } 25 \text {, } \\
26,43\end{array}$ \\
\hline ---- & ---- & $\cdots$ & ---- & low frown & ---- & 4 \\
\hline glare & $---\infty$ & $\cdots$ & $\cdots$ & $\cdots$ & ---- & $4+5$ \\
\hline \multicolumn{7}{|c|}{ Part 3: Units in the Lower Face, Mouth, and Cheeks } \\
\hline mouth in repose & ---- & $+\cdots$ & ---- & basic mouth & ---- & $\cdots$ \\
\hline nose wrinkle & 51. wrinkle & $\begin{array}{l}\text { wrinkling the } \\
\text { nose }\end{array}$ & nose wrinkle & screw face & $\begin{array}{l}42 \text { nasal bridge } \\
\text { is furrowed (DR) }\end{array}$ & 9 or $9+25$ \\
\hline ---- & $-\cdots$ & $-\cdots--$ & $-\cdots$ & lip up & ----- & 10 or $\mathrm{R} 10$ or $\mathrm{L} 10$ \\
\hline right sneer & 40. \&sneer & $\cdots$ & $\cdots$ & \&sneer & $\begin{array}{l}\& 61 \text { upper lip } \\
\text { raised on one } \\
\text { side(CS) }\end{array}$ & $\begin{array}{l}\mathrm{R} 9 \text { or } \mathrm{R} 10^{* * * * *} \\
\text { may include } 25,26\end{array}$ \\
\hline
\end{tabular}


APPENDIX B (continued)

\begin{tabular}{|c|c|c|c|c|c|c|}
\hline $\begin{array}{l}\text { Birdwhistell } \\
(1970)\end{array}$ & $\begin{array}{l}\text { Grant } \\
(1969)\end{array}$ & $\begin{array}{l}\text { Blurton-Jones } \\
(1971)\end{array}$ & $\begin{array}{l}\text { McGrew } \\
(1972)\end{array}$ & $\begin{array}{l}\text { Brannigan \& } \\
\text { Humphries (1972) }\end{array}$ & $\begin{array}{l}\text { Izard } \\
\text { MAX (1983)* } \\
\text { (Affex) }\end{array}$ & \begin{tabular}{l}
\multicolumn{1}{c}{ Reference } \\
Ekman \& Friesen \\
FACS (1978)
\end{tabular} \\
\hline left sneer & 40. \&sneer & ----- & $-\cdots$ & \&sneer & $\& 61$ & $\begin{array}{l}\mathrm{L} 9 \text { or } \mathrm{L} 10^{* * * *} \\
\text { may include } 25,26\end{array}$ \\
\hline -.--- & ---- & squared upper lip & ----- & ---- & $\cdots$ & $\begin{array}{l}(9 \text { or } 10)+25 \text { or } \\
9+10+25\end{array}$ \\
\hline ----- & $\cdots$ & squared lower lip & bared teeth & $-\cdots--$ & ---- & $\begin{array}{l}16+(25 \text { or } 26) \text { or } \\
15+16+(25 \text { or } 26) \\
\text { may include } 31\end{array}$ \\
\hline ---- & ---- & $\cdots$ & ----- & $-\cdots$ & $\begin{array}{l}63 \text { lower lip is } \\
\text { lowered and slight- } \\
\text { ly forward (DR) }\end{array}$ & $16+25$ \\
\hline ---- & 39. intension bite & ----- & 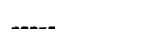 & intension bite & $-\cdots$ & $16+25+29$ \\
\hline ---- & ----- & ---- & $-\cdots$ & $\cdots$ & $\begin{array}{l}54 \text { angular, } \\
\text { squarish mouth } \\
\text { (AR, DP) }\end{array}$ & $\begin{array}{l}9+16+(25 \text { or } 26) \\
\text { may include } 20\end{array}$ \\
\hline$\cdots$ & ---- & $---\cdot$ & $-\cdots$ & ---- & $\begin{array}{l}\text { 59B opened, tense, } \\
\text { angular mouth with } \\
\text { tongue forward } \\
\text { (DR) }\end{array}$ & $9+16+19+26$ \\
\hline ? retreating lips & ----- & $-\cdots$ & $-\cdots$ & squared mouth & $-\cdots$ & $10+16+(25$ or 26$)$ \\
\hline $\begin{array}{l}\text { smile tight- } \\
\text { loose o }\end{array}$ & 20. simple smile & $\begin{array}{l}\text { \&mouth corners } \\
\text { raised }\end{array}$ & \&smile & \&simple smile & $\begin{array}{l}\& 52 \text { corners or } \\
\text { angle of mouth } \\
\text { pulled back and up } \\
\text { (EJ) }\end{array}$ & $\begin{array}{l}12 \mathrm{X} \text { or } 12 \mathrm{Y}^{* * *} \\
\text { may include } 7\end{array}$ \\
\hline ---- & 21. wide smile & $\begin{array}{l}\text { \&mouth corners } \\
\text { raised }\end{array}$ & \&smile & \&simple smile & $\& 52$ & $\begin{array}{l}12 \mathrm{Y} \text { or } 12 \mathrm{Z}^{* * *} \\
\text { may include } 6,7\end{array}$ \\
\hline ----- & 22. grin & ----- = & \&smile & grin & ---- & $\mathrm{R} 12$ or $\mathrm{L} 12 * * * *$ \\
\hline $\begin{array}{l}\text { ? toothy } \\
\text { smile }\end{array}$ & 23. upper smile & $\begin{array}{l}\text { \&mouth corners } \\
\text { raised }\end{array}$ & \&smile & upper smile & $\& 52$ & $\begin{array}{l}12+(25 \text { or } 26) \\
\text { may include } 6,7\end{array}$ \\
\hline ----- & $\begin{array}{l}\text { 24. lip-in } \\
\text { smile }\end{array}$ & $\begin{array}{l}\text { \&mouth corners } \\
\text { raised }\end{array}$ & \&smile & lip-in smile & $\cdots$ & $\begin{array}{l}12+26+\mathrm{B} 28 \text { or } \\
12+26+\mathrm{B} 32 * * * *\end{array}$ \\
\hline $\begin{array}{l}\text { ? square } \\
\text { smile }\end{array}$ & 25. broad smile & $\begin{array}{l}\text { \&mouth corners } \\
\text { raised }\end{array}$ & \&smile & broad smile & $\& 52$ & $\begin{array}{l}(6 \text { or } 7)+12+16+ \\
(25 \text { or } 26)\end{array}$ \\
\hline ----- & --- & $\begin{array}{l}\text { \&mouth corners } \\
\text { raised }\end{array}$ & play face & play face & ---- & $\begin{array}{l}8+12+(26 \text { or } 27) \\
\text { or } 12+(26 \text { or } 27)\end{array}$ \\
\hline ---- & 26. open grin & ---- & \&smile & $\begin{array}{l}\text { open grin (may } \\
\text { be bilateral) }\end{array}$ & ---- & $\begin{array}{l}\mathrm{R} 12+(25 \text { or } 26) \\
\mathrm{L} 12+(25 \text { or } 26) \\
* * * *\end{array}$ \\
\hline ----- & 27. oblong smile & $\begin{array}{l}\text { \&mouth corners } \\
\text { raised }\end{array}$ & \&smile & oblong smile & ---- & $12+25+29$ \\
\hline---- & ---- & $-\cdots$ & ----- & wry smile & $-\cdots--$ & $\begin{array}{l}\mathrm{R} 12+\mathrm{L} 15 \text { or } \\
\mathrm{L} 12+\mathrm{R} 15^{* * * *}\end{array}$ \\
\hline ---- & ---- & --- & ---- & compressed smile & $\cdots$ & $\begin{array}{l}12 \mathrm{X}+23 \text { or } \\
12 \mathrm{X}+24^{* * *}\end{array}$ \\
\hline ----- & $\begin{array}{l}28 . \text { mouth corners } \\
\text { back }\end{array}$ & \&lips retracted & --. & $\begin{array}{l}\text { mouth corners } \\
\text { back }\end{array}$ & ---- & $\begin{array}{l}20 \text { or } 12+15 \\
\text { may be } 12 \text { or } 14\end{array}$ \\
\hline ---- & 29. oblong mouth & \&lips retracted & grin face & $\begin{array}{l}\text { mouth corners } \\
\text { out }\end{array}$ & $\begin{array}{l}53 \text { slightly opened } \\
\text { mouth with } \\
\text { corners retracted } \\
\text { straight back (FT) }\end{array}$ & $\begin{array}{l}20+(25,26, \text { or } 27) \\
\text { may include } 10,16\end{array}$ \\
\hline -..- & $-\cdots$ & ---- & $\cdots$ & oblong mouth & ---- & $\begin{array}{l}20+25+29 \\
\text { may include } 10,16\end{array}$ \\
\hline ---- & ----- & ---- & ---- & $\begin{array}{l}\text { mouth corners } \\
\text { tremble }\end{array}$ & ---- & 15 or 20 or $15+20$ \\
\hline ? droopy mouth & $\begin{array}{l}\text { 32. mouth cor- } \\
\text { ners down }\end{array}$ & $\begin{array}{l}\text { mouth corners } \\
\text { lowered }\end{array}$ & ----. & $\begin{array}{l}\text { mouth corners } \\
\text { down }\end{array}$ & $\begin{array}{l}56 \text { corners of } \\
\text { mouth drawn } \\
\text { downward and } \\
\text { outward (SD) }\end{array}$ & 15 or 17 or $15+17$ \\
\hline pout & $\begin{array}{l}\text { 33. lower lip } \\
\text { out }\end{array}$ & $\begin{array}{l}\text { lower lip } \\
\text { pout }\end{array}$ & \&pout & $\begin{array}{l}\text { lower lip } \\
\text { out }\end{array}$ & ---- & 17 \\
\hline ----- & ---- & $-\cdots$ & $\cdots$ & scowl & $\cdots$ & $15+17$ \\
\hline
\end{tabular}


APPENDIX B (continued)

\begin{tabular}{|c|c|c|c|c|c|c|}
\hline & & & & & Izard & Reference \\
\hline $\begin{array}{l}\text { Birdwhistell } \\
(1970)\end{array}$ & $\begin{array}{l}\text { Grant } \\
(1969)\end{array}$ & $\begin{array}{l}\text { Blurton-Jones } \\
(1971)\end{array}$ & $\begin{array}{l}\text { McGrew } \\
(1972) \\
\end{array}$ & $\begin{array}{l}\text { Brannigan \& } \\
\text { Humphries (1972) }\end{array}$ & $\begin{array}{l}\text { MAX }(1983)^{*} \\
\text { (Affex) }\end{array}$ & $\begin{array}{l}\text { Ekman \& Friesen } \\
\text { FACS (1978) }\end{array}$ \\
\hline ---- & $\begin{array}{l}\text { 34. lower lip } \\
\text { tremble }\end{array}$ & ----- & ----- & $\begin{array}{l}\text { lower lip } \\
\text { tremble }\end{array}$ & ---- & $\begin{array}{l}17 \text { or alternating } \\
17 \text { and } 16\end{array}$ \\
\hline --- & 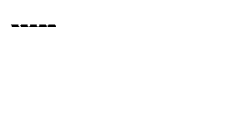 & ---- & $\cdots$ & $\ldots$ & $\begin{array}{l}55 \text { mouth open, } \\
\text { stretched tense } \\
\text { (AR, DP) }\end{array}$ & $\begin{array}{l}27 \text { may include } \\
9,10,16 \text {, or } 20\end{array}$ \\
\hline ---- & 36. lips forward & two lip pout & \&pout & lips forward & $-\cdots$ & $\begin{array}{l}17 \text { or } 22 \text { or } 17+22 \\
\text { or } 22+25 \text { or } \\
17+22+25\end{array}$ \\
\hline ---- & -..-- & $-\cdots$ & $\cdots+$. & point & ---- & 22 \\
\hline pursed lips & 42. purse & $\begin{array}{l}\text { contraction of } \\
\text { orbicularis oris }\end{array}$ & ---- & purse & ---- & $\begin{array}{l}18 \text { or } 18+(23 \text { or } \\
24)\end{array}$ \\
\hline ---- & 37. small mouth & ---- & ----- & small mouth & $\begin{array}{l}65 \text { pursed lips } \\
\text { (IE) }\end{array}$ & $\begin{array}{l}18 \text { may include } \\
24 \text { or } 25\end{array}$ \\
\hline ---- & 38. tight lips & $\begin{array}{l}\text { lips pressed } \\
\text { together }\end{array}$ & ---- & tight lips & ---- ～～～ & 23 or 24 \\
\hline ---- & 41 twist mouth & ---- & $-\cdots$ & twist mouth & ---- & $\begin{array}{l}\text { G18 or } \mathrm{H} 18 \text { may } \\
\text { include } 20,23 \text {, } \\
24 * * * *\end{array}$ \\
\hline ---- & ---- & $\begin{array}{l}\text { lengthing the } \\
\text { upper lip }\end{array}$ & -...- & $\cdots$ & $\cdots$ & 8 or 22 \\
\hline ---- & ----- & lips touching & ---- & ---- & ---- & ---- \\
\hline ? lax mouth & ---- & $\begin{array}{l}\text { lips slightly } \\
\text { apart }\end{array}$ & \&mouth open & ---- & ---- & 25 \\
\hline \&open mouth & \&44. open mouth & $\begin{array}{l}\text { lips clearly } \\
\text { apart }\end{array}$ & \&mouth open & \&open mouth & $\begin{array}{l}51 \text { open, relaxed } \\
\text { mouth (IE) }\end{array}$ & 26 \\
\hline ---- & ---- & ---- & ---- & ---- & $\begin{array}{l}50 \text { open, roundish } \\
\text { or oval mouth } \\
\text { (SS) }\end{array}$ & $\begin{array}{l}26 \text { or } 27 \text { or } \\
18+(26 \text { or } 27)\end{array}$ \\
\hline \&open mouth & \&44. open mouth & lips wide apart & \&mouth open & \&open mouth & 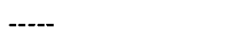 & 26 or 27 \\
\hline dropped jaw & -.-- & $\cdots$ & 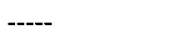 & 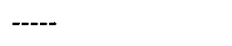 & ---- & 26 or 27 \\
\hline -.-- & 35. lips in & lips rolled in & ---- & lips in & $\begin{array}{l}64 \text { lower lip } \\
\text { (or both) rolled } \\
\text { inward (SH) }\end{array}$ & 28 \\
\hline \&lip biting & \&43. bite lip & upper lip bitten & \&chew lips & \&bite lip & ---- ～～～～ & $\mathrm{t} 32$ \\
\hline \&lip biting & \&43. bite lip & lower lip bitten & \&chew lips & \&bite lip & $\cdots$ & b32 \\
\hline slow lick-lips & \&30. lick lips & ---- & \&lick & $-\cdots$ & $\cdots$ & 37 \\
\hline quick lick-lips & \&30. lick lips & $-\cdots$ & \&lick & lick & ---- & 37 \\
\hline moistening lips & $\cdots$ & ---- & \&lick & ---- & ---. & 37 \\
\hline$\cdots$ & ----- = & tongue invisible & ----- & ---- & $\cdots$ & ---- \\
\hline --- & \&45. tongue & tongue visible & ---- & ---- & ---- & ---- \\
\hline ---- & \&45. tongue & $\begin{array}{l}\text { tongue pushed } \\
\text { forward }\end{array}$ & \&tongue out & $\begin{array}{l}\text { tongue between } \\
\text { lips }\end{array}$ & $\begin{array}{l}66 \text { tongue } \\
\text { forward }\end{array}$ & $19+26$ \\
\hline -.-- & ----- & ----- & ---- & $\cdots-$ & $\begin{array}{l}\text { 59A open, relaxed } \\
\text { mouth with tongue } \\
\text { forward (IE) }\end{array}$ & $19+26$ \\
\hline ---.. & 46. tongue out & $\begin{array}{l}\text { tongue out of } \\
\text { mouth }\end{array}$ & \&tongue out & tongue out & $-\cdots$ & $19+(26$ or 27$)$ \\
\hline tongue in cheek & $\cdots$ & ---- & -.-- & ----- & $\cdots$ & 36 \\
\hline---- & ---- & no teeth show & ---- & -..- & --- & $\cdots$ \\
\hline -.-- & $\cdots$ & upper teeth show & ---- & $--\cdot$ & $\cdots$ & ---- \\
\hline ---- & ---- & lower teeth show & $-\cdots$ & ---- & --- & $\cdots$ \\
\hline -.-- & $-\cdots$ & both show equally & $--\cdot-$ & $\cdots$ & ---- & ---- \\
\hline$---\cdot$ & ---- & $\begin{array}{l}\text { upper teeth } \\
\text { show more }\end{array}$ & $\cdots$ & ---- & $-\cdots$ & ---- \\
\hline$\cdots$ & $-\cdots$ & $\begin{array}{l}\text { lower teeth } \\
\text { show more }\end{array}$ & ----- & -.-- & ---- & --- \\
\hline 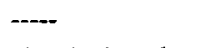 & --- & tooth grinding & grind teeth & ---- & $\cdots$ & --- \\
\hline clenched teeth & ----- & clenched molars & $\cdots$ & ---- & $\cdots$ & 31 \\
\hline
\end{tabular}


APPENDIX B (continued)

\begin{tabular}{|c|c|c|c|c|c|c|}
\hline & & & & & & Reference \\
\hline $\begin{array}{l}\text { Birdwhistell } \\
(1970)\end{array}$ & $\begin{array}{l}\text { Grant } \\
\text { (1969) }\end{array}$ & $\begin{array}{l}\text { Blurton-Jones } \\
(1971)\end{array}$ & $\begin{array}{l}\text { McGrew } \\
(1972)\end{array}$ & $\begin{array}{l}\text { Brannigan \& } \\
\text { Humphries (1972) }\end{array}$ & $\begin{array}{l}\text { MAX (1983)* } \\
\text { (Affex) }\end{array}$ & $\begin{array}{l}\text { Ekman \& Friesen } \\
\text { FACS (1978) }\end{array}$ \\
\hline chin protruding & ---- & clenched incisors & $\cdots$ & ----- & ----- & 29 \\
\hline set jaw & $-\cdots$ & $-\cdots$ & -.-- & ---- & $\cdots$ & ---- \\
\hline$\cdots$ & $-\cdots$ & $\begin{array}{l}\text { jaw moved } \\
\text { sideways }\end{array}$ & $\cdots$ & ----- & $\cdots$ & 30 \\
\hline pinched nostrils & $-\cdots$ & ---- & ---- & ----- & ---- & 39 \\
\hline bunny nose & ---- & ----- & ---- & $\cdots$ & ---- & $\cdots$ \\
\hline curled nostril & $\cdots$ & ---- & ---- & ---- & ---- & R38 or L38**** \\
\hline flaring nostrils & $\cdots--$ & ---- ～～～～～～ & ---- & flare & ---- & 38 \\
\hline$-\cdots$ & $\cdots$ & indented cheeks & -...- & --- & ---- & 35 \\
\hline -..- ～～～～～ & $\cdots$ & puffed cheeks & $\cdots$ & ---- & ---- & 34 \\
\hline ? blank faced & $\cdots$ & ---- & normal face & normal face & 0 & 0 \\
\hline chewing & $-\cdots$ & $\cdots$ & $--\cdot$ & chew & $\cdots$ & $\cdots$ \\
\hline --- & 31. swallow & ---- & swallow & -..- & ---- & $\cdots$ \\
\hline peck & --- & ---- & \&kiss & \&kiss & $\cdots$ & $\cdots$ \\
\hline smack & ---- & --- & \&kiss & \&kiss & $\cdots$ & ---- \\
\hline whistle & $-\cdots$ & ---. & $\cdots$ & --- & $\cdots$ & --- \\
\hline ---- & ---- & $---\cdot$ & spit & spit & ---- & $\cdots$ \\
\hline$\cdots$ & ---- & $\cdots$ & $\cdots$ & intension speak & $-\cdots$ & $\cdots$ \\
\hline $\begin{array}{l}\text { out of the side } \\
\text { of the mouth (left) }\end{array}$ & $\cdots$ & $--\cdots$ & ---- & $\cdots$ & $\cdots$ & $-\cdots$ \\
\hline $\begin{array}{l}\text { out of the side } \\
\text { of the mouth (right) }\end{array}$ & 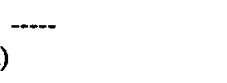 & $\cdots$ & $\cdots$ & ---- & --- & ---- \\
\hline 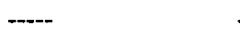 & ---- & ---- & verbalize & ----- & ---- & $-\cdots$ \\
\hline$\cdots$ & $\cdots$ & ---- & vocalize & ----- & ---- & ---- \\
\hline ----- & --- & ---- & mouth & ---- & --- & ---- \\
\hline ---- & ---- & ---- & laugh & ---- & $\cdots$ & --- \\
\hline$\cdots$ & $\cdots$ & $\cdots--$ & bite & ----- & $\cdots$ & $\cdots$ \\
\hline$-\cdots$ & $\cdots$ & $\cdots$ & blow & ----- &.--- & $\cdots$ \\
\hline$-\cdots$ & 47. yawn & $\cdots$ & yawn & yawn & ---- & 27 \\
\hline---- & $\cdots$ & ---- & ----- & grimace & ---- & $\begin{array}{l}6+9+15+25 \\
\text { may include } 43\end{array}$ \\
\hline ----- & 48. head forward & ---- & $\cdots$ & head forward & $\cdots$ & 57 \\
\hline ---- & 49. threat & ----- & $-\cdots$ & threat & ----- & 57 \\
\hline ---- & 50. chin out & $-\cdots--$ & $\cdots$ & chin out & ---- & 53 \\
\hline ----- & ----- & $\cdots-\cdots$ & face thrust. & ----- & ----- & $53+57$ \\
\hline$\cdots$ & 53. chin in & --- & chin in & chin in & ---- & 58 \\
\hline \multicolumn{7}{|c|}{ Part 4: Units of the Whole Face and Head } \\
\hline ---- & 52. evade & ----- & $\cdots$ & evade & ---- & ----- \\
\hline $\begin{array}{l}\text { cocked head } \\
\text { (six varieties) }\end{array}$ & 56. head to side & head on side & hẹad tilt & head to side & $\cdots$ & 55 or 56 \\
\hline ---- & 58. jerk & ----- & $\cdots$ & jerk & ---- & head positions** \\
\hline ---- & 57. bob & ---- & ---- & bob & ---- & 53 \\
\hline ---- & ----- & ---- & $-\cdots$ & hang & ---- & 54 \\
\hline ----- & ----- & ----- & $\cdots$ & level & ---- & ---- \\
\hline$--\cdots$ & 60 . head rock & $\cdots$ & ---- & head rock & $\cdots$ & 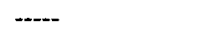 \\
\hline $\begin{array}{l}\text { full nod up and } \\
\text { down or down and } \\
\text { up (six varieties) }\end{array}$ & \&54. nod & ---- & \&head nod & \&nod & ----- & head positions** \\
\hline $\begin{array}{l}\text { haif nod either } \\
\text { up or down (six } \\
\text { varieties) }\end{array}$ & \&54. nod & ---- & \&head nod & \&nod & $\cdots--$ & head positions** \\
\hline $\begin{array}{l}\text { small bounce at } \\
\text { end of head nod } \\
\text { (six varieties) }\end{array}$ & \&54. nod & ---- & \&head nod & \&nod & $\cdots$ & head positions** \\
\hline
\end{tabular}


APPENDIX B (continued)

\begin{tabular}{|c|c|c|c|c|c|c|}
\hline & & & & & Izard & Reference \\
\hline $\begin{array}{l}\text { Birdwhistell } \\
(1970)\end{array}$ & $\begin{array}{l}\text { Grant } \\
(1969)\end{array}$ & $\begin{array}{l}\text { Blurton-Jones } \\
\text { (1971) }\end{array}$ & $\begin{array}{l}\text { McGrew } \\
(1972)\end{array}$ & $\begin{array}{l}\text { Brannigan \& } \\
\text { Humphries (1972) } \\
\end{array}$ & $\begin{array}{l}\text { MAX (1983)* } \\
\text { (Affex) }\end{array}$ & $\begin{array}{l}\text { Ekman \& Friesen } \\
\text { FACS (1978) }\end{array}$ \\
\hline $\begin{array}{l}\text { tense medial } \\
\text { multiple nod } \\
\text { (two varieties) }\end{array}$ & \&54. nod & ----- & \&head nod & \&nod & --.-- & head positions** \\
\hline $\begin{array}{l}\text { full side and } \\
\text { back sweep } \\
\text { (six varieties) }\end{array}$ & \&55. shake & \&head shake & \&head shake & \&shake & ---- & head positions ${ }^{* *}$ \\
\hline $\begin{array}{l}\text { half sweep } \\
\text { (six varieties) }\end{array}$ & \&55. shake & \&head shake & \&head shake & \&shake & ----- & head positions** \\
\hline $\begin{array}{l}\text { small bounce at } \\
\text { end of sweep } \\
\text { (six varieties) }\end{array}$ & \&55. shake & \&head shake & \&head shake & \&shake & $\cdots--$ & head positions** \\
\hline $\begin{array}{l}\text { tense medial } \\
\text { multiple sweep } \\
\text { (two varieties) }\end{array}$ & \&55. shake & \&head shake & \&head shake & \&shake & 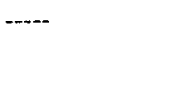 & head positions** \\
\hline -...- & $\begin{array}{l}\text { 56. head } \\
\text { movement }\end{array}$ & ---- & ---- & head movement & -..-- & head positions** \\
\hline ear wiggle & ---- & $\cdots$ & $\cdots$ & ----- & ----- & $\ldots$ \\
\hline $\begin{array}{l}\text { total scalp } \\
\text { movement }\end{array}$ & -.-- & ---- & $\cdots$ & ----- & ---- & ---- \\
\hline temples tightened & ---- & $\cdots$ & $-\cdots$ & $---\cdot$ & -ב--- & ---- \\
\hline ----- & 62. smooth face & ---- & $-\cdots$ & smooth face & ---- & ---- \\
\hline ----- & 116. blush & ---- & red face & facial reddening & --.-- & -.-- \\
\hline ----- & 117. blanch & $\cdots+-$ & $-\cdots-$ & blanch & -.-- & ---- \\
\hline -.-- & 118. sweat & --- & $\cdots$ & sweat & ----- & $\cdots$ \\
\hline$-\cdots$ & ---- & $\begin{array}{l}\text { bilateral } \\
\text { asymmetry }\end{array}$ & $\cdots$ & ---- & ---- & $\begin{array}{l}\mathrm{R} \text { or } \mathrm{L}^{* * *} \\
\mathrm{G} \text { or } \mathrm{H}\end{array}$ \\
\hline
\end{tabular}

Note - -... = No equivalent unit. ? = Unit may not be equivalent to others on the same line. \& = Unit appears on more than one line. $*$ Each unit in Izard's MAX is followed in parentheses by the affect units in his Affex (Izard et al., 1983) technique which could be coded when these appearance changes are observed. See the text for a discussion. $I E=$ interest; $E J=$ joy; $S S=$ surprise; $S D=$ sadness; $A R=a n g e r ; D R$ $=$ disgust; $C S=$ contempt; $F T=$ fear; $S H=$ shame-guilt-shyness; $D P=$ discomfort-pain. $\quad * * H e a d$ positions (units $50-59$ ) and eye positions (units 60-69) allow scoring many head and eye movements. ****The $X$ suffix indicates low intensity; the $Y$ suffix, moderate intensity; the $Z$ suffix, high intensity. Intensity distinctions are made when relevant to definitions. ${ }^{* * * *}$ The $R$ prefix indicates actions only on the right side of the face; the $L$ prefix, actions only on the lefi. In later scoring additions, the prefixes $G$ and $H$ indicated right and left asymmetry, but asymmetry scoring is an additional step (e.g., see Hager \& Ekman, 1985). B prefix indicates bottom of lip; $T$, top.

(Manuscript received December 13, 1984; revision accepted for publication June 14,1985 .) 